\title{
Murgul ve Lahanos Volkanojenik Masif Sülfür (VMS) Cevherleşmelerinin Cevher Mineralojisi (KD Türkiye): Doğu Pontidlerin Zıt Uçlarında Yer Alan İki Cevherleşmenin Karşılaştırması

\author{
Ore Mineralogy of Murgul and Lahanos Volcanogenic
} Massive Sulfide (VMS) Mineralizations (NE Turkey): A comparison of two mineralizations from opposite ends of the Eastern Pontides \\ Mehmet Akbulut ${ }^{*} \mathbb{E}$
}

${ }^{1}$ Dokuz Eylül Üniversitesi Mühendislik Fakültesi Jeoloji Mühendisliği Bölümü Tınaztepe Kampüsü Buca-İZMİR Sorumlu Yazar / Corresponding Author*: makbulut@deu.edu.tr

$\ddot{0} \mathbf{z}$

Türkiye'nin kuzeydoğusunda yer alan Doğu Pontid Metalojenik Kuşağl, volkanojenik masif sülfür cevherleșmelerini barındırmaktadır. Bu çalıșmada bölgenin doğu ve batı uçlarında yer alan Murgul ve Lahanos bakır yataklarının cevher mineralojileri karşılaştırılmalı olarak incelenmiştir. Yeni veriler, her iki yatağın bölgedeki Üst Kretase yay volkanizmasının gelişimi sırasında iki farklı volkanik evre arasında gelişmiş deniz tabanı hidtotermal aktivitesinin ürünleri olduğunu desteklemektedir. Murgul yatağı bu tip sistemlerdeki saçınım ve stokvörk beslenme kanallarını, Lahanos yatağı ise reküranslar gösteren parajenezle karakterize denizaltı sülfür yığınlarını iyi şekilde temsil eder. Bu çalışmada adı geçen yataklardan verilen parajenetik bilgiler, ana cevherleşme evrelerinin zamanlaması ve/veya cevherleşme sonrası rejüvenasyon süreçlerinin daha iyi anlaşılmasında, ve bölgesel metalojenezik yap-bozun diğer eksik parçalarının tamamlanmasında yardımcı olacağı düşünülen ve daha sonrasına yönelik planlanan direkt cevherden radyometrik yaş çalışmaları ve cevher mineral kimyası çalışmaları için önemli bir altlık veri sağlamaktadır.

Anahtar Kelimeler: Volkanojenik Masif Sülfür Yatakları, Kuroko-tipi, Murgul, Lahanos, Doğu Pontidler

\section{Abstract}

The Eastern Pontide Metallogenic Belt located to the northeast of Turkey hosts massive sulfide mineralizations. In this study, ore mineralogy of the Murgul and Lahanos copper deposits located to the eastern and western ends of the region is comperatively investigated. The new findings supports that both deposits are products of seafloor hydrothermal activity that occurred between two different volcanic episodes of the Upper Cretaceous arc volcanism in the region. Murgul deposit highly represents the disseminated and stockwork feeder channels of such systems, whilst the Lahanos 
deposit highly represents the seafloor sulfide mounds characterized by paragenesis with recurrences. The paragenetic information given in this study provides important background data for later planned studies on direct radiometric dating of the ore minerals and ore mineral chemistry, which are expected to give a better understanding of the timing of main ore-forming stages and/or postmineralization rejuvenation processes, and help filling the missing parts of the regional metallogenic puzzle.

Keywords: Volcanogenic Massive Sulfide Deposits, Kuroko-type, Murgul, Lahanos, Eastern Pontides

\section{Giriș}

Volkanojenik masif sülfür (VMS) yatakları: denizaltı volkanik ortamında deniz tabanında (veya yakınında) denizaltı hidrotermal konvenksiyonu ile ilișkili olarak metalce zengin akışkanların deşarjı ile gelişen mercek ve/veya levha-benzeri şekilli polimetalik masif sülfür çökelimleridir $[1,2]$. Tipik olarak felsik, mafik ve/veya bimodal volkanik kayalar ve sedimenter kayalar eşliğinde gözlenen höyügüumsü veya tablamsı şekilli masif sülfür mercekleri ve bunların altında yer alan yarı-uyumlu uyumsuz ağsal ve saçınım sülfür cevherleşmeleri şeklindedirler. Temelde bakır, çinko ve kurşun, yan ürün olarak ise genelde gümüş ve altının yanı sıra kalay, kadmiyum, antimon ve bizmut eldesinde kullanılabilen metal kaynaklarıdır [3].

Arkeen'den Miyosen'e denizel volkanizmanın geliştiği hemen tüm kuşaklarda gözlenen VMS yataklarının günümüz okyanus ortası açılma ve/veya yay ortamlarındaki hidrotermal baca komplekslerinde (kara tütenler- black smokers) izlenen hidrotermal sisteme benzer süreçlerle geliştiği düşünülmektedir. Temelde sülfür açısından doygun karmaşık hidrotermal akışkanlar denizaltı volkanizmasının duraksadığı/durduğu dönemlerde süreksizlikler (faylar ve kırık sistemleri) boyunca deniz tabanına taşınarak burada sülfür çökelimlerine neden olmaktadır. Cevherleşme sonrası yenilenen volkanizma veya sedimentasyon yatakların örtülmesine sebep olmaktadır. Bu tip yataklar genellikle ada yayları ve yay-gerisi açılma alanlarının geliştiği paleotektonik ortamlarda yoğunlaşmaya meyillidir. Tetis okyanusunun dinamikleri ile meydana gelmiş bir şerit kara parçası olarak niteleyebilceğimiz Türkiye'de de çok büyük olmasa da çok sayıda ve çoğu dünya literatüründe bilinen VMS yatakları egemen olarak dar sütur kuşakları ve paleo-yay segmentlerinde yığılmıştır (özellikle Pontid Metalojenik Kuşağı ve Bitlis-Zagros Metalojenik
KușağınınTürkiye'deki kuzeybatı segmenti, Șekil 1a).

Alp-Himalaya Kuşağının en iyi korunmuş kıtasal yaylarından biri olan Doğu Pontidlerin jeolojisi hakkında çalıșmalar 1800'lü yıların ortalarına kadar uzanmaktadır [4]. Bu ilk çalıșmadan sonrada bölgede çok sayıda farklı çalışma gerçekleștirilmiș, bölgede yer alan VMS yatakları ve konak kayaçları günümüze kadar bir çok araştırmacı tarafından ele alınmıştır [5-105]. Bilimsel önemleri yanında bu yataklar her zaman bakır (ve bazen de kurşun-çinko) madenciliği açısından önemli arama ve işletmle hedefleri olmuş ve olmaya devam etmektedir.

$\mathrm{Bu}$ yatakların bazılarının deniz tabanı üzerinde (sea-floor) moloz/kütle akmaları şeklinde, bazılarının ise deniz tabanının hemen altındaki ornatma süreçleriyle oluştuğu önerilmiştir [106]. Bu çalışmada Doğu Pontidler magmatik yayının doğu ve batı uç kesimlerinde yer alan Murgul ve Lahanos bakır yataklarının jeolojik ve tektonik özellikleri derlenmeye/özetlenmeye çalışılmış ve cevher mineralojileri incelenmiștir. Aynı hedef metal kaynağına sahip olmalarına rağmen birbirlerinden hem mineralojik, hemde kimyasal olarak dikkat çekici şekilde farklılıklar sunan bu yatakların incelenmesinin bölge cevherleşmelerinin daha iyi anlaşılmasına katkı sunması beklenmektedir.

\section{Bölgesel Jeoloji}

Paleo- ve Neo-Tetis okyanusal havzaları, Paleozoyik ve Mezozoyik zamanlarında kuzeyde yer alan Lavrasya ve güneydeki Gondwana kıtalarının arasında açllan ve kapanan havzalardır[107]. Bu havzaların kapanması ile doğan mikro-kıtalar kolajının en önemli sonucu Tetis-Avrasya Metalojenik Kuşağı'dır (TAMK; Şekil 1a, [108, 109]). Coğrafik olarak batı Avrupa'da İtalya'dan başlayıp, Doğu Avrupa üzerinden Anadolu, Orta Doğu ve Orta Asya ve Himalayaları kateredek Güneydoğu Asya'ya kadar uzanan çok geniş bir metalojik kuşak 
olarak tanımlanabilecek bu zon cok sayıda metalojenik ve önemli alt metalojenik kușaklara ayrılır (Şekil 1b). TAMK'nın Türkiye segmenti de, kompleks jeolojik/tektonik yapısı nedeniyle, VMS, skarn, porfiri, epitermal ve Demir Oksit Bakır Altın (DOBA) gibi bir çok farklı mineralizasyon türünün toplandığı orojenik/metalojenik kuşaklar içerir [108, 110, 111]. Bunlardan en önemlilerinden biri de Türkiye'nin kuzeydoğusunda yer alan ve dar bir Geç Kretase magmatik yay segmentinin kalıntılarını içeren Doğu Pontid Metalojenik Kuşağı'dır (DPMK).

Samsun'un kuzeybatısından Artvin'e kadar sahil șeridi boyunca uzanan ve güneye, Anadolu'nun içine doğru, yaklașık $180 \mathrm{~km}$ genișlikte değerlendirilen bu orojenik/metalojenik kuşağın oluşumunu bazı araştırmacılar PaleoTetis'in okyanusal litosferinin kuzeye doğru [112-116], bazlları ise güneye doğru yitimi ile $[66,117,118,119,120]$ açılklamakta; Şengör ve Yılmaz ise [51] güneye doğru başlayıp sonra kuzeye dalımla devam eden bir paleotektonik tarihçe önermektedir [121]. Pontidlerdeki yay magmatizmasının, Ladiniyen-Noriyen riftleşmesi ile açlan Neo-Tetis'in okyanus tabanının Türoniyen'den itibaren Pontidler altına -muhtemelen kuzeye doğru-dalması ile geliștiği düşünülmektedir [122 ve orada verilen referanslar]. Bu bölgedeki VMS yatakları, çeşitli araştırmacılar tarafından kuzeyden güneye (kuzey, güney ve eksenel olarak) üç alt zona ayrılan doğu Pontid orojenik kuşağının [121, 123, 124] Karadeniz tarafinda kalan kuzey alt zonunda doğudan batıya doğru sıralanmıș şekilde yer alırlar (Șekil 1c).

Bölgede yer yer 3000 metre kalınlığa varan ve geç Mezozoyik-Senozoyik dönemine ait volkanik yayın ürünleri olan volkano-sedimenter istifin temel olarak üç ana evreden oluşan episodik bir volkanizmanın ürünü olduğu belirtilmektedir [127-130]. Bunlardan ilk ikisi Üst Kretease bimodal yay volkanizmasını temsil eder (Şekil 2). Apsiyen'den başlayarak Türoniyen'e kadar devam eden 1. Evrénin bașlangıcında volkanizmanın bazaltik-andezitik bileșimi baskındır [121]. Çatak Formasyonu olarak adlandırılan, kireçtaşı ve marn arakatkıları içeren volkanosedimenter istifin gelişimi sonrası, Türoniyen-Santoniyen aralığında toleyitik ve kalk-alkali bir felsik volkanizma etkindir (Şekil 2).

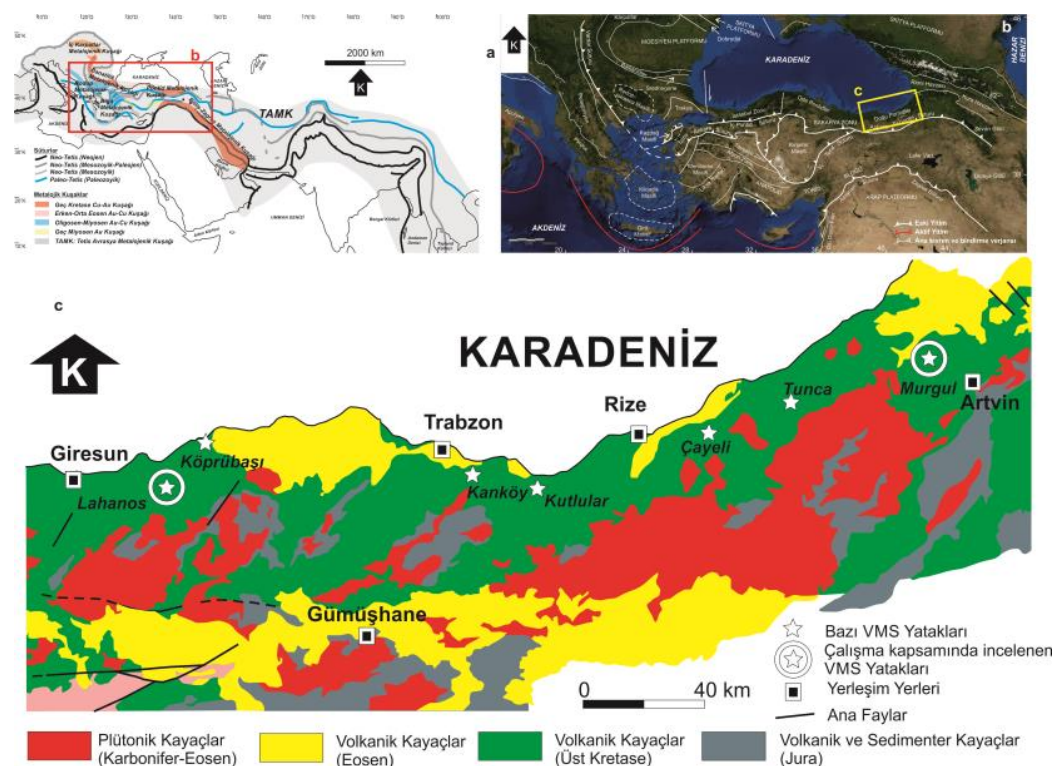

Şekil 1. (a) Tetis Avrasya Metalojenik Kuşağı (TAMK) ve içerdiği bazı alt metalojenik kuşakların yerleri $[107,108]$, (b) Tetis Metalojenik Kușağının bir parçası olan Doğu Akdeniz bölgesinde yer alan kıtasal bloklar ve ana sütur zonları [125'den değiștirilerek]. Şekildeki tektonik süturlar [126], uydu görüntüsü altık ise Esri, DigitalGlobe, GeoEye, i-cubed, USDA, USGS, AEX, Getmapping, Aerogrid, IGN, IGP, swisstopo, ve GIS User Community'den], (c) Doğu Pontidlerin basitleştirilmiş jeolojisi ve VMS yataklarının yerleri [106'dan değiştirilerek]. 
$\mathrm{Bu}$ felsik volkanizma dasit-riyodasit-riyolit bileșimli volkanik ürünler ve kireçtașı ve marn ara katkılarının gözlendiği bir volkanosedimenter istifin (Kızılkaya Formasyonu) oluşumuna neden olmuştur ([121], Şekil 2).

Üst Kreatase bimodal volkanizmasının 2 . Evresi'nin bașında da (Santoniyen) yine bazaltikandezitik volkanizma egemendir (Şekil 2). Bu bazaltik-andezitik volkanizma ürünleri ve sedimenter arakatkılarını (Çağlayan Formasyonu) Geç Santoniyen'de gelișen ve 1 . Evre felsik volkanizmasından șoșonitik bileșimi ile ayrılan biyotit içerikli riyolit ve riyodasit lav ve piroklastiklerinden olușan son evre takip eder (Tirebolu veya Çayırbağ Formasyonu) [121].

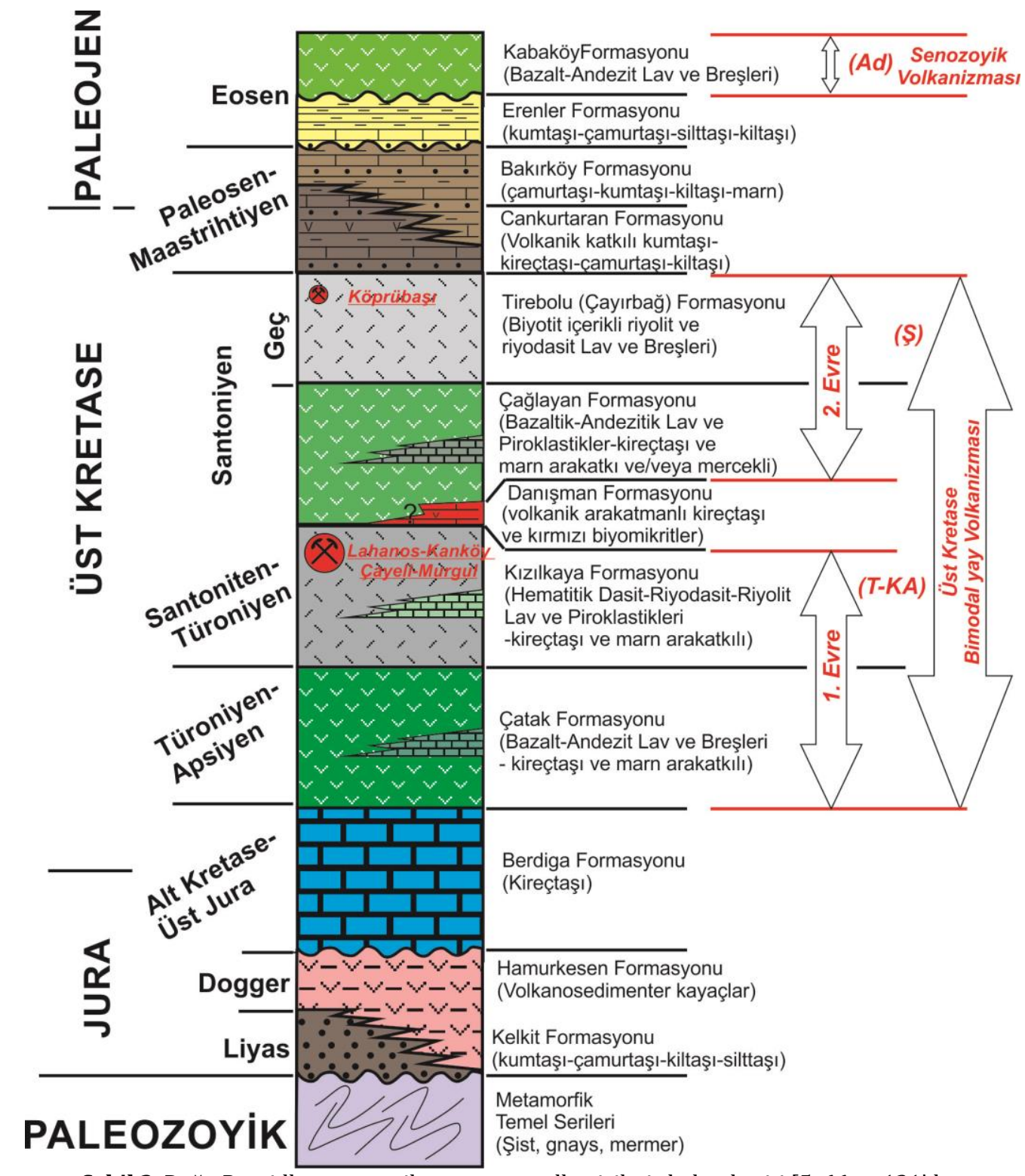

Şekil 2. Doğu Pontidler magmatik yayının genelleştirilmiș kolon kesiti [5, 66 ve 121'den deneştirilerek]. Kuroko-tipi VMS yataklarının geliştiği seviyeler [66] ve [121]'den derlenmiștir. T$K A$ :Toleyitik ve Kalk-alkalen; $S$ :şoşonitik; Ad: Adakitik 
Doğu Pontidler'de, Senozoyik'te etkili olan 3. Evre volkanizmasının ise bașlangıçta, Geç Paleosen-Erken Eosen'de, adakitik karakterli olduğu ifade edilmektedir [121].

Doğu Pontidler'deki VMS yatakları genel olarak hematitik dasit-riyodasit lav, dom ve piroklastikler ve ilişkili kireçtaşı ve marn arakatmanları șeklinde tanımlanan Kızılkaya Formasyonu ve kısmen de volkanizmada daha üst seviyeleri temsil eden biyotit içerikli riyolit ve riyodasitler olarak tanımlanan Tirebolu (veya Çayırbağ) Formasyonu içinde, genelde bu her iki volkanik formasyonun da piroklastik ürünlerinde yer alır $[121,131]$. Bölgedeki VMS yatakları genelde dissemine şekilde, damarlar, damarcıklar ve nadiren de masif cevher șeklinde gözlenir [131]. Yataklarda ana metal zenginleşmeleri genelde $\mathrm{Fe}$ ve $\mathrm{Cu}$ sülfürlerin baskın varlığ șeklindedir ve bölgede temel olarak $\mathrm{Cu}$ cevher üretimi gerçekleștirilmektedir. Bazı yataklarda önemli oranda $\mathrm{Pb}$ ve $\mathrm{Zn}$ varlığı söz konusudur ve bu metaller açısından ön plana çıkmaktadırlar (örn, Harşit-Köprübaşı gibi, [132]). Cevherleșmelerin konak ve çevre kayaçlarında silisleşme ve arjilitleşme türü alterasyonlar yaygındır ve cevherleșmeler genelde paleomorfolojik yükseltiler (antiklinal ve domlar) ve çöküntüler (kaldera ilișkili yapılar) ile ilișkili olarak gözlenir [131]. Mekan kayaları (ada yayı volkanizmasını yansıtan felsik bimodal volkanizma ürünleri), cevher yapı ve dokuları (baskın şekilde ağsal ve saçınım cevher ve eşleniğinde az oranda masif cevher mercekleri) ve metal içerikleri (Cu-Fe-Zn) göz önüne alınarak bu yataklar bir çok yazar tarafindan genel anlamda Kuroko tipi VMS yataklarının doğu Pontidlerde yer alan eşlenikleri olarak değerlendirilmektedir [örn., 86, 133]. Ancak son yıllarda bazı araştırmacılar jeodinamik ortam ve mekan kaya kimyaları açısından klasik Kuroko-tip VMS'lerden farklılıklarına da dikkat çekmektedir [örn., 5, 121].

\section{Materyal ve Metodlar}

$\mathrm{Bu}$ çalışmada incelenen cevher örnekleri Murgul yatağında aynı kotta yanal yönde, Lahanos yatağında ise yatağın farklı seviyelerini temsil edecek șekilde farklı kotlardan alınmıștır. Cevher örnekleri öncelikle tasnif edilerek özelliklerine göre ince ve/veya parlak kesitler ve kimyasal analizler için gruplandırılmıș ve çalışılmıştır.
İnce ve parlak kesitler ve kimyasal analiz numuneleri Dokuz Eylül Üniversitesi Jeoloji Mühendisliği Bölümü İnce Kesit ve Gemoloji Laboratuvarı ve Örnek Hazırlama Laboratuvarı'nda hazırlanmıștır. İnce ve parlak kesit çalışmaları Dokuz Eylül Üniversitesi Jeoloji Mühendisliği Bölümü sıvı Kapanım ve Cevher Mikroskopisi/Petrografisi Laboratuvarında yürütülmüștür.

Cevher örneklerinin tüm kayaç kimyasal analizleri ALS Minerals Ltd. (Türkiye/Kanada) laboratuvarlarında gerçekleștirilmiştir. Örnekler cevher derecesinde örneklerin analizine uygun șekilde dört asit çözündürme yöntemi ile çözeltiye alınmıștır. Ag, $\mathrm{As}, \mathrm{Bi}, \mathrm{Cd}, \mathrm{Cu}$, $\mathrm{Fe}, \mathrm{Pb}, \mathrm{S}$ ve $\mathrm{Zn}$ analizleri ICP-AES sistemi ile tamamlanmıştır. Au değerleri ise ateş tahlili ve takip eden AAS çalışması ile belirlenmiştir. Kükürt analiz alt ve üst limitleri \% 0,01-50'dir.

\section{Murgul Bakır Yatağı}

Doğu Pontidlerin en doğusunda, Gürcistan sınırı yakınında bulunan Murgul $\mathrm{Cu}$ yatağı, Artvin ilinin Murgul ilçesine bağlı Damar köyünün güneybatısında yer alır (Şekil 1c, 2 ve $3 a$ ). Kuzeyde Damar (Anayatak) ve güneyde Çakmakkaya olmak üzere iki cevherleşme olarak açık işletme şeklinde değerlendirilen Murgul yatağı üzerine geçmiș dönemlerde çok sayıda jeolojik, petrografik, cevher mikroskopisi, kükürt, oksijen, hidrojen izotopları, sıvı kapanım ve rezerv/tenöre yönelik çalışmalar gerçekleştirilmiştir $[5,89,90$ ve buralarda sunulan kaynaklar]. Bu çalıșmalarda detaylı şekilde ele alınan yataklardan Damar cevherleşmesinde günümüzde için üretim faaliyetleri tamamlamış görünmekte, üretim sadece Çakmakkaya cevherleşmesinde gerçekleştirilmektedir (Şekil 3a). Çakmakkaya ve Damar cevherleşmeleri çevresinde yüzeyleyen kayaçlar Gökçe tarafından alttan üste andezitik lav, breșleșmiș dasit tüf, örtü tüfü ve porfiri dasit şeklinde tanımlanmıştır [89]. Çakmakkaya cevherleşmesinde ana cevher yüzlekte açı-yeşilimsi beyaz renklerde gözlenen "Breşleşmiş Dasitik Tüf" birimi içinde ağsal ve saçınım șeklinde gözlenmekte, bu zon bordo-mor renkli ayrışma yüzey rengi nedeniyle "mor tüf" adı da verilen örtü tüfü ile üstlenmektedir (Şekil 3a ve 3b). Ancak Gökçe, bu mor tüf birimi içinde de yaygın halde özşekilli ve iri pirit kristallerinin varlığından söz eder [89]. Lokal olarak breşleşmiş dasit tüf ve örtü tüfleri 
olarak adlandırılmıs olan birimlerin genelleştirilmiş kolon kesitte tanımlanan Kızılkaya Formasyonu'nun üyeleri ile eşleştiği düşünülmektedir. Cevherleșmeyle ilișkili ana alterasyon fazları silisleşme, arjilitleşme ve fillitik alterasyon olarak tanımlanmaktadır [95]. Önceki çalışmalarda Çiftçi [133] tarafından Çakmakkaya cevherleşmesi için baskın cevherleșme olarak bahsedilen ve Gökçe [89] tarafından da buradaki ağsal tipi cevher zonunun kuzeybatı ucunda üst ve kenar kesimlerde ince bir zon șeklinde tanımlanan masif cevher seviyesi (ve beraberindeki mercek şekilli jips zonu) günümüzde açılan açık işletme basamaklarında gözlenememekte, üretim stokvörk ve saçınım cevher içeren breşleşmiş dasit tüften gerçekleştirilmektedir (Şekil 3b). Ağsal cevherde damarcık kalınlıkları Gökçe tarafindan $1 \mathrm{~mm}$ - $15 \mathrm{~cm}$ arasında [89] tanımlanmıştır. $\mathrm{Bu}$ çalışmanın örneklerinin alındığı arazi çalıșmalarında da incelenen yüzleklerde ağsal damarcık kalınlıklarının genelde $\leq 15 \mathrm{~cm}$ civarında olduğu gözlenmiștir (Şekil 3c). Arazi çalışmalarında ayrıca, damacıklarda ve konak kayada saçınım halinde makroskopik baskın cevher fazlarının pirit ve kalkopirit olduğu, baskın gang mineralinin ise kuvars olduğu gözlenmiștir.

Bu çalışmada Murgul Çakmakkaya yatağından alınan cevher örneklerinden gerçekleştirilen analizlerde $\mathrm{Cu}$ miktarı ağ. \% 0,49-1,87 arasında değişmektedir $(n=3$, Tablo 1$) . P b$ ve $\mathrm{Zn}$ miktarları düșüktür (sırasıyla ağ. \% 0,003-0,006 ve $0,003-0,016)$. Ana olarak pirit varlığından kaynaklanan $\mathrm{Fe}$ ve kükürtlü fazlardan gelen $\mathrm{S}$ miktarları sırasıyla ağ. \% 4,11-11,45 ve 4,3612,7 arasındadır. Au ve Ag ortalama tenörleri ise 0,25 ve 3,67 ppm olarak saptanmıştır.

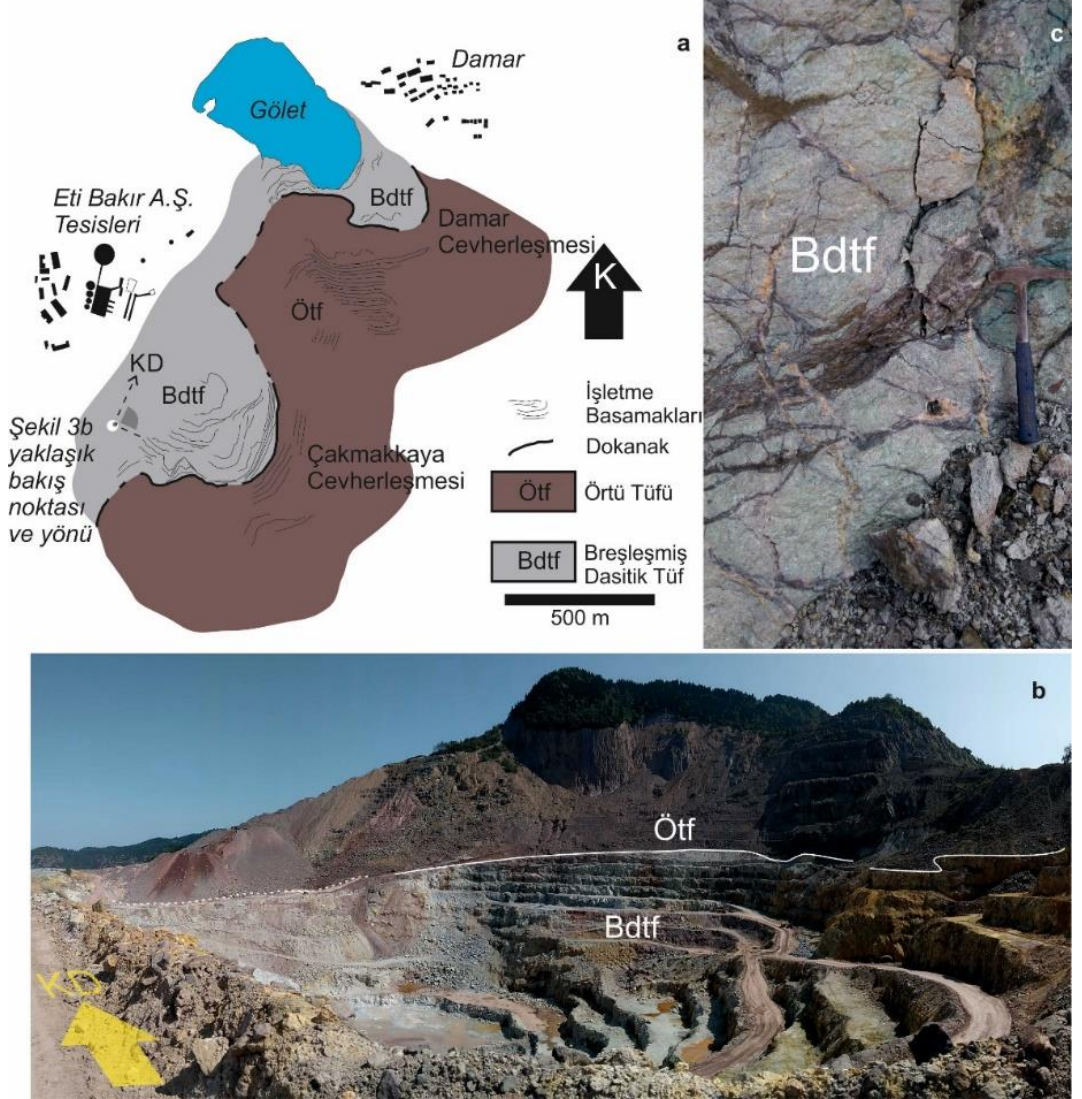

Şekil 3. (a) Murgul Cu yatağı basitleştirilmiş jeoloji haritası, (b) 3a'daki gösterilen yaklaşık bakış noktasından konak breșleșmiș dasit tüf içindeki Çakmakkaya cevherleșmesinin ve örtü tüfün dokanağının kuzeydoğuya doğru görüntüsü, (c) Breşleşmiş dasit tüf içinde gözlenen stokvörk damarcıklar ve saçınım şeklindeki cevherleşme 
DEU FMD 22(64), 117-136, 2020

Tablo 1. Murgul Çakmakkaya ve Lahanos Bakır Yataklarından alınan cevher örneklerine ait analiz sonuçları.

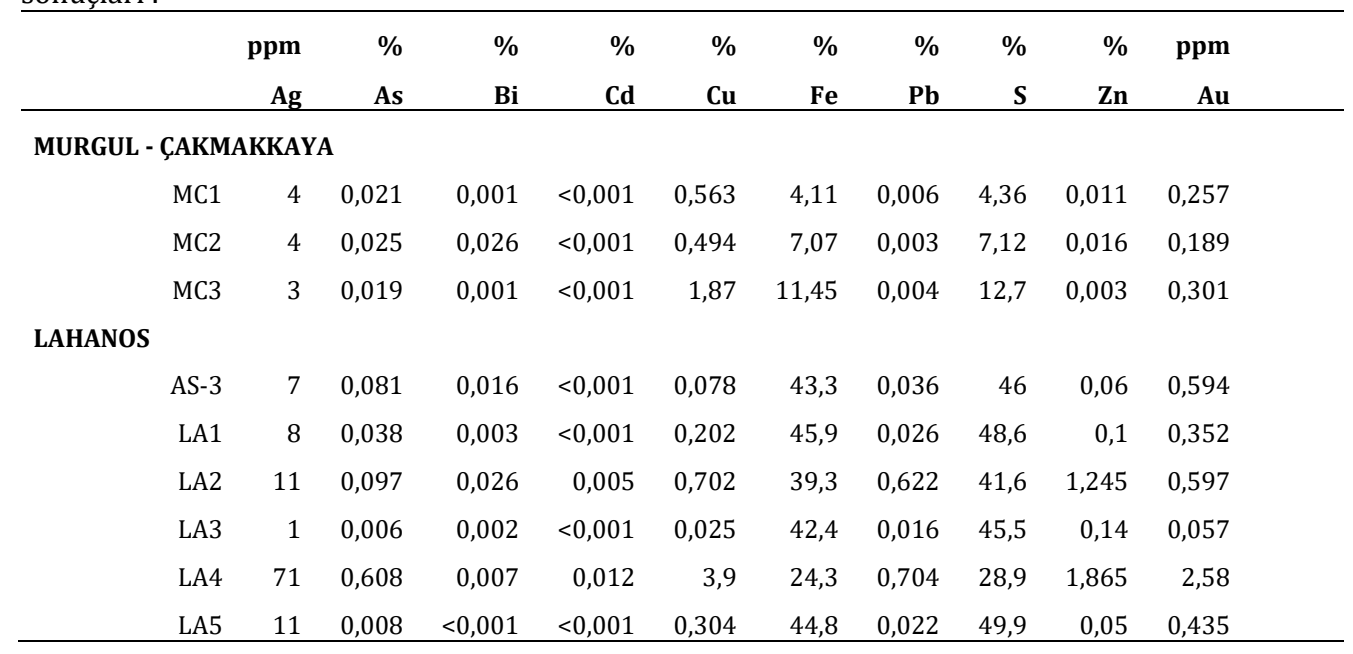

\section{Lahanos Bakır Yatağı}

Doğu Pontidler metalojenik kuşağının en batı kesiminde, Giresun il sınırları içinde yer alan Lahanos yatağı'da Murgul yatağı gibi temel olarak $\mathrm{Cu}$ içeriği açısından değerlendirilen bir yataktır(Şekil 1c). Kızılkaya formasyonu olarak tanımlanan, marn ve kireçtaşı arakatkılı dasitriyodasit-riyolitlerden oluşan volkanosedimanter formasyonun üst kesimlerinde yer alan Lahanos masif cevheri "yatak dasiti" [97] olarak ta adlandırılan otobreșik dasitik lavlardan ibaret "Konak Dasit" içinde ve üzerinde gelişmiştir (Şekil 4a, 4b ve 4c). Silişleşme, killeșme, serizitleșme ve kloritleșmenin gözlendiği bu taban (ve konak) dasitik kayalarının üzerinde yer alan masif cevher temelde yer yer $\mathrm{Cu}$ ve $\mathrm{Zn}$ içeriği zengin piritik bir kütledir. Genel olarak kırıntılı (klastik) bir yapı sunan masif cevher gövdesi tabandan tavana sırasıyla masif piritik cevher $(\mathrm{Cu}<1$ ve eser miktarda $\mathrm{Zn})$, piritli masif cevher $(\mathrm{Cu}>\mathrm{Zn})$ ve masif cevher $(\mathrm{Zn}>\mathrm{Cu})$ șeklinde zonlara ayrılmaktadır [5]. Taban kayaları ve masif cevher horizonu üzerinde ise hematitik dasit, hyaloklastit ve volkano-sedimanter elemanlar içeren baskın olarak kırmızımsı (morumsu) yer yer gri renkli volkanik üyelerden oluşmuş "Tavan Birimleri" yer almaktadır. Tavan birimlerinde de serizitleşme ve kloritleşme gözlenmektedir ve bunlar "Lahanos Tepe dasiti" olarak ta adlandırılan intrüzif karakterli biyotitli dasit birimi (Tirebolu Formasyonu?) tarafindan üstlenirler [5].

Lahanos yatağında da Murgul'da olduğu gibi cevherleşmenin içinde ve üzerinde geliştiği mekan kayalar (konak dasit veya otobreşik dasit) ve tavan birimleri olarak tanımlanan örtü kayaçların (hematitik dasit, mor dasit vb.) Kızılkaya Formasyonu'nun üyeleri ile eşleștiği düşünülmektedir. Bölgede yapılan önceki çalışmalar ve gözlemlerin deneștirilmesi ile oluşturulmuş litostratigrafik bir korelasyon şeması Şekil 5'te verilmiştir.

Bu çalıșmada Lahanos yatağından alınan cevher örneklerinden gerçekleştirilen analizlerde $\mathrm{Cu}$ miktarı ağ. \% 0,03 ile 3,90 arasında değişmektedir $(n=6$, Tablo 1$) . P b$ ve $\mathrm{Zn}$ miktarları Murgul yatağına göre daha yüksektir (sirasiyla ağ. \% 0,02-0,70 ve 0,05-1,86). Ana olarak pirit varlığından kaynaklanan $\mathrm{Fe}$ ve kükürtlü fazlardan gelen S miktarları sırasıyla ağ. $\% 24,30-45,90$ ve $28,90-49,90$ arasındadır. Au ve Ag ise ortalama 0,77 ve 18,17 ppm olarak saptanmıştır. 


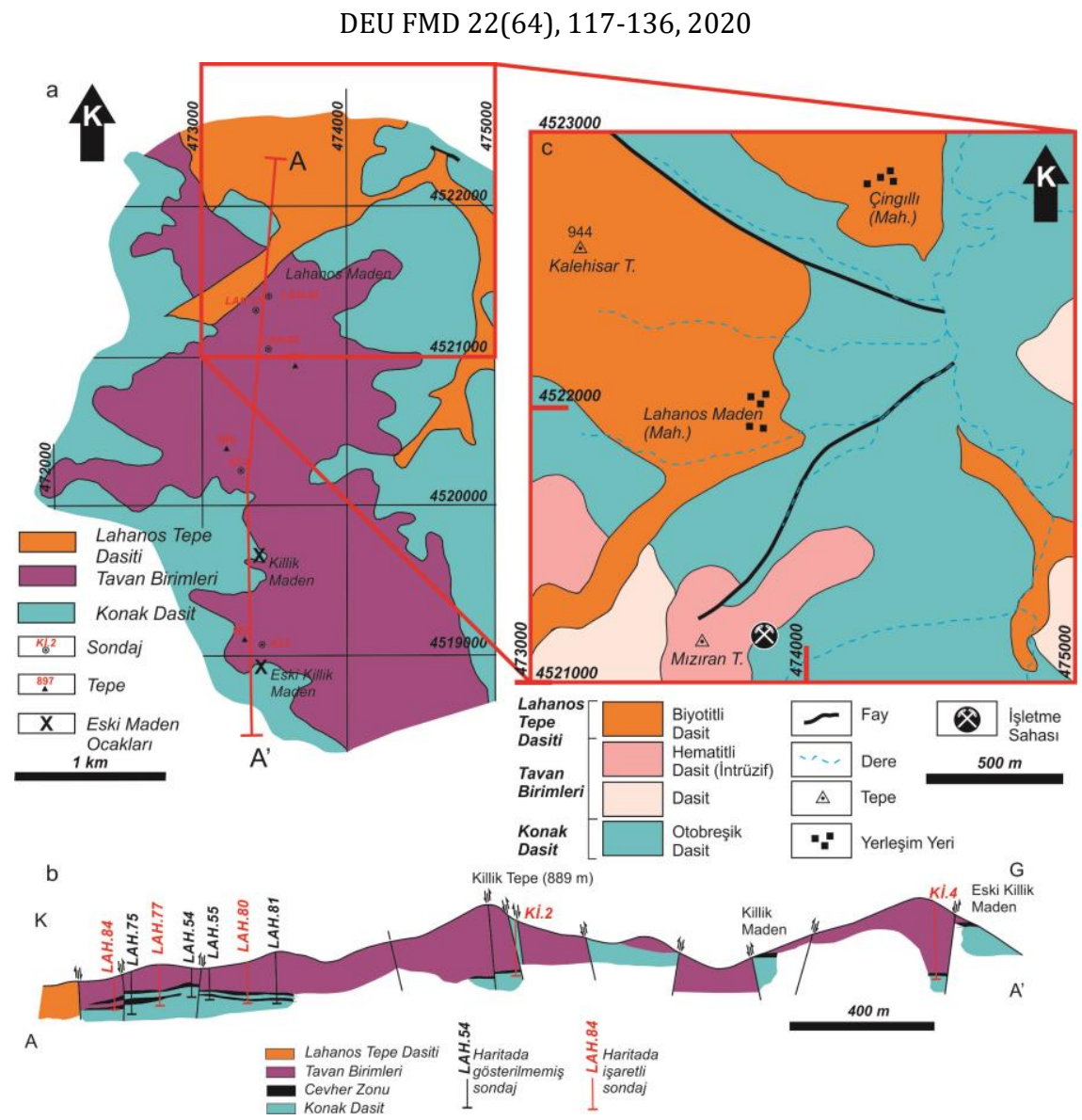

Şekil 4 (a) Lahanos Cu yatağı jeoloji haritası[133'den derlenerek], (b) Sondajlardan ve yüzey jeolojisinden yararlanarak oluşturulmuş A-A' kesiti [97 ve 133'den deneștirilerek ], (c) 4a'daki gösterilen 4 km'lik alanın detay jeolojisi[5, 97 ve 133'den deneștirilerek.

\section{LAHANOS}

[5]'ten değiștirilerek

\begin{tabular}{l} 
Tirebolu (Çayırbağ) Formasyonu \\
(Biyotit (çerikli riyolit ve \\
riyodasit Lav ve Breşleri) \\
\hline Cağlayan Formasyonu \\
(Bazaltik-Andezitik Lav ve \\
Piroklastikler-kireçtaşı ve \\
marn arakatkı ve/veya mercekli) \\
\hline Danışman Formasyonu \\
(volkanik arakatmanlı kireçtaşı \\
ve kırmızı biyomikritler) \\
\hline Kızılkaya Formasyonu \\
(Hematitik Dasit-Riyodasit-Riyolit \\
Lav ve Piroklastikleri \\
-kireçtaşı ve marn arakatkılı) \\
\hline Catak Formasyonu \\
(Bazalt-Andezit Lav ve Breşleri \\
- kireçtaşı ve marn arakatkılı)
\end{tabular}

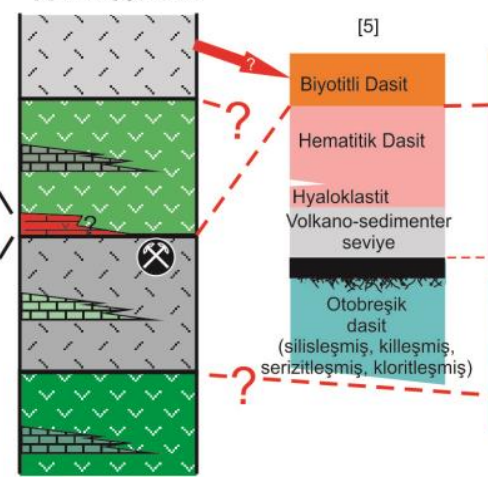

[97], [135], [136]

MURGUL

[97], [89], [135]

Şekil 5. Lahanos ve Murgul yataklarının litostratigrafisinin Doğu Pontidler magmatik yayının genelleștirilmiş kolon kesiti ile deneştirilmesi. Deneştirmede kullanılan kolon kesitlerin kaynakları ilgili kesitlerin üzerinde verilmiştir. 


\section{Cevher Mineralojisi}

Çalışma kapsamında gerçekleștirilen arazi çalışmaları sırasında Murgul ve Lahanos $\mathrm{Cu}$ yataklarından alınan cevher örneklerinden hazırlanan parlak ve ince kesitler yansıyan ışık mikroskopisi yardımıyla incelenmiştir. $\mathrm{Bu}$ çalışmalar kapsamında elde edilen gözlem ve bulgular aşağıda sunulmuştur.

\subsection{Murgul $\mathrm{Cu}$ yatağı cevher ve gang parajenezi}

Önceki çalışmalarda Murgul yatağı için baskın șekilde pirit ve kalkopiritten olușan ve lokal olarak galen, sfalerit ve fahlerz grubu mineraller içeren bir parajenezden bahsedilmiş, bunlara eser oranda aikinit $\left(\mathrm{PbCuBiS}_{3}\right)$, hessit $\left(\mathrm{Ag}_{2} \mathrm{Te}\right)$, tetradimit $\left(\mathrm{Bi}_{2} \mathrm{Te}_{2} \mathrm{~S}\right)$, clausthalit $(\mathrm{PbSe})$, nabit altın, cervelleit $\left(\mathrm{Ag}_{4} \mathrm{TeS}\right)$, stützit $\left(\mathrm{Ag}_{5-\mathrm{x}} \mathrm{Te}_{3}\right), \mathrm{Bi}-$ tenantit ve Bi-selenotellürid gibi minör fazların eşlik ettiği belirtilmiştir [137, 138]. Yine önceki çalışmalarda cevherleşmenin ilk evresinin kuvars ve serizit ile karakterize bir filllik alterasyon ve eşleniğindeki arjilik alterasyon ile, ikincil evresinin ise temel olarak kuvars ve jasper ile karakterize yoğun bir silisik alterasyon ile ilişkili olduğu belirtilmektedir [101]. Bu çalışma kapsamında yataktan alınmış örneklerde gözlenen cevher ve gang mineralleri parajenezi ise daha yalındır. Parlak ve ince kesitlerde gözlemlenen parajenez iki farklı evrede ve dokuda gelişmiş pirit (öhedral/subhedral ve framboyidal), kalkopirit, bornit, kovellin, sfalerit, kuvars, serizit ve kil minerallerinden ibarettir. Lokal olarak gözlendiğinden bahsedilen galen, sfalerit ve fahlerz grubuna ve eser olarak bulunduğu belirtilen bizmut, tellür ve selenidli fazlara rastlanamamıștır.

İncelenen örneklerde cevher süksesyonunun öhedral/subhedral piritler (pirit-I) ile bașladı ̆̆ görülmektedir (Şekil 6a). Bu ilk evre pirit oluşumu genelde öncelikle framboyidal piritler (pirit-II) tarafından ornatılmış, ardından da kalkopirit tarafından çevrelenmiş şekilde gözlenmektedir (Şekil 6a ve 6b). Framboyidal piritlerin de incelenen kesitlerde yaygın şekilde kalkopirit tarafından ornatıldığı görülmektedir (Şekil 6c). Kesitlerden ana sülfür cevherleșmesinin volkanik mekan kayacın silisleşmesi ve ağsal şekilde sülfürlü ve silisli damarcıkların yerleşimi ile ilişkili olduğu görülmektedir (SSekil 6d ve 6e). Kuvars, ağsal damacıklarda iri taneli ve tarak (comb) dokusu sunar şekilde gözlenirken, mekan kayacın silisleşmesi sürecinde gelişen kuvars tanelerinin orta-ince taneli olduğu ve yap-boz (jigsaw) dokusu sunduğu görülmektedir (Şekil 6e). Ayrıca parlak kesitlerde öhedral/subhedral piritleri (pirit-I) ornatır şekilde olduğu gözlenen framboyidal piritlerin (pirit-II) baskın olarak silisleșmiş mekan kaya içinde bulunduğu, tarak dokulu iri kristalli ağsal damarcıklarda ise bu fazlara rastlanmadığı görülmektedir (Şekil 6d). Kesitlerde ayrıca silisleşme öncesi feldspatlardan türeyen erken evre alterasyon ürünü serizitler ve arjilikleşme de gözlenmektedir (Şekil 6f).

Murgul yatağından alınan örneklerden oluşturulan bir parajenez tablosu Şekil 7'de verilmiştir. 

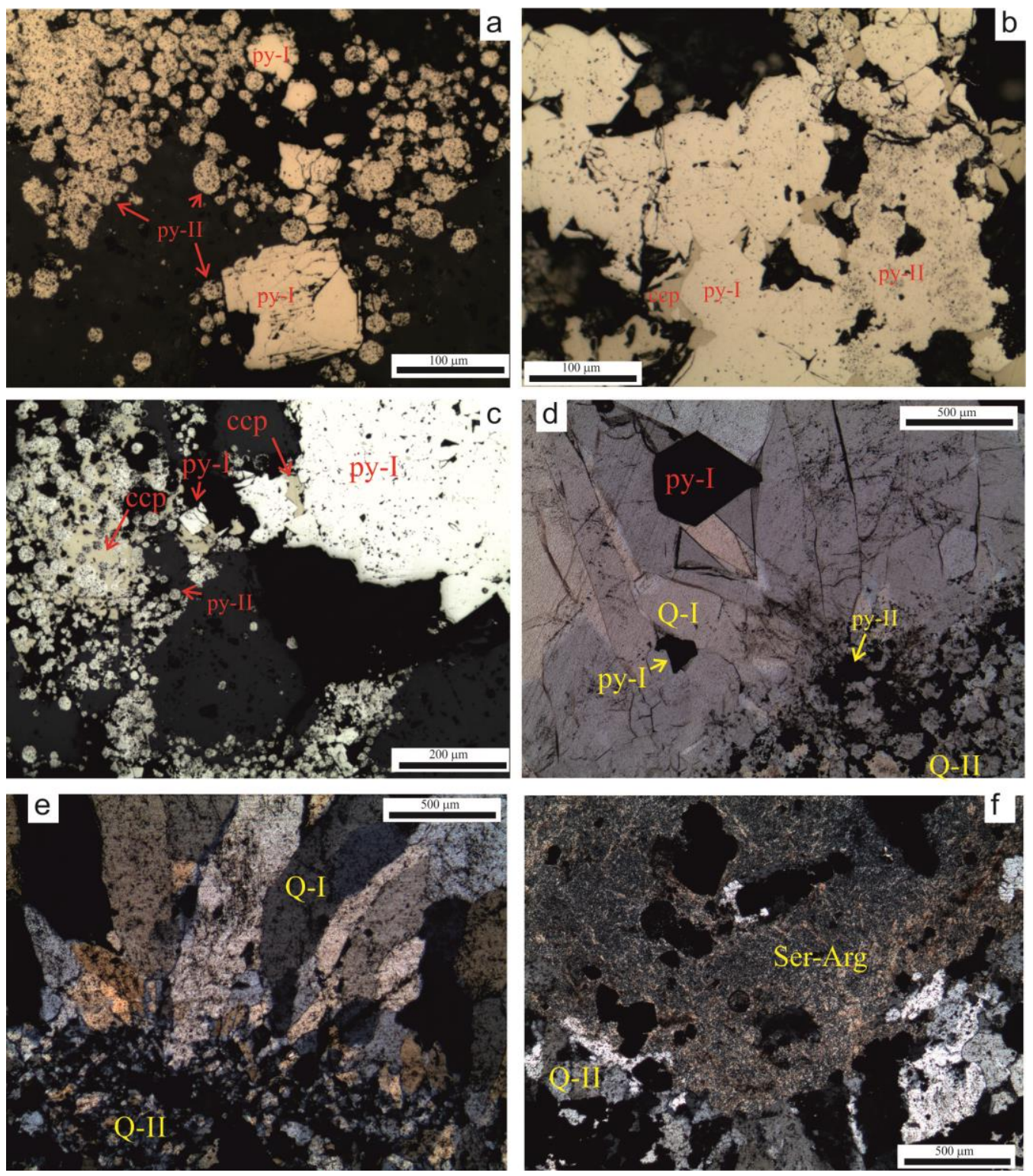

Şekil 6. Murgul yatağından alınan cevherleșme örneklerinden ince ve parlak kesit fotoğrafları. (a)

Öhedral/subhedral piritler (py-I) ve onları ornatan framboyidal piritler (py-II), (b) ve (c)

Öhedral/subhedral piritlerin framboyidal piritler ve kalkopirit (ccp) tarafından ornatımı, (d) ve (e) tarak (comb) dokulu ve iri taneli kuvars (Q-I), konak kayacın yoğun silisleşmesi ile oluşan yap-boz (jig-saw) dokulu orta-ince taneli kuvars (Q-II) ve eşlik eden cevher mineralleri, (f) silisleşme öncesi erken evre alterasyonu ile ilksel feldspatlardan gelișen serizitleşme ve arjilikleşme (Ser-Arg).

Yansıyan ışık görüntüleri havada ve tek nikolde, polarizan mikroskop görüntülerinden sadece $6 \mathrm{~d}$ paralel, diğerleri çapraz nikolde alınmıștır. 


\begin{tabular}{|l|c|c|}
\hline \multicolumn{1}{|c|}{ Mineral } & 1. Evre & \multirow{2}{*}{ 2. Evre } \\
\hline Serizit & \multicolumn{2}{|c|}{} \\
Kil Mineralleri & \multicolumn{2}{|c|}{} \\
Pirit-I & & \\
Pirit-II & & \\
Kalkopirit & & \\
Kuvars-I & & \\
Kuvars-II & & \\
\hline
\end{tabular}

Şekil 7. Murgul yatağından alınan örneklere ait genelleștirilmiş parajenetik sekans.

\subsection{Lahanos $\mathrm{Cu}$ yatağı cevher ve gang parajenezi}

Önceki çalışmalarda Lahanos yatağına ait cevher parajenezi ifade edilirken baskın olarak $\mathrm{Fe}, \mathrm{Cu}$, $\mathrm{Zn}, \mathrm{Pb}$ sülfürlerin ve nadiren de arsenürlü fazların varlığından söz edilmiştir [5, 97, 135, 136]. Bu çalışma kapsamında da Lahanos yatağından alınmış örneklerden hazırlanmıș parlak kesitlerde yapılan incelemelerde önceki çalışmalarda verilen parajenez ve süksesyonu genel olarak destekler bulgulara rastlanmıştır. Ancak bazı farklılıklar da göze çarpmaktadır ve bunlara aşağıda değinilmektedir.

Zengin bir parajenetik topluluk içeren cevherleșmenin en dikkat çekici özelliği sergilediği karmaşık süksesyondaki mineral tekrarlanması yaygınlığıdır. Bunların daha iyi anlaşılabilmesi için cevherleşmede tekrarlanan mineraller numaralandırılmıștır. $\mathrm{Bu}$ numaralandırmada temel olarak dokusal farklılıklar ve oluşum sırasını gösteren kenetlenme ilişkileri göz önüne alınmıștır. Fazların kimyasal bileşimlerine dair bir değerlendirmeye gidilmemiştir. İncelenen örneklerde parajenez temel olarak, üç farklı dokusal özellikte pirit (I-II ve III), üç farklı kalkopirit ve sfalerit (I-II ve III), iki farklı evrede gelişmiş tenantit (I ve II), bunlara ek olarak enarjit, galen, kovellit, kalkosit, bornit, ve tüm bu cevher minerallerine eşlik eden barit ve kuvarstan oluşmaktadır.

Masif cevher kütlesinin alt seviyelerinden alınmış örneklerde piritçe zengin bir mineralizasyon hakimdir. Temel olarak yaygin șekilde konsantrik ve bantll, yer yer süngerimsi ve/veya framboyit benzeri toplanımlar şeklinde piritlerle (pirit-I) başlayan cevherleşme, bunların subhedral-öhedral ve daha iri taneli piritler (pirit-II) tarafından ornatılması ile devam etmiştir. (Şekil 8a). Birinci evre piritleri ornatan bu subhedral-öhedral piritlerin oluşturduğu kovuklu yapı içinde bunlardan sonra gelişen kalkopirit (kalkopirit-I) ve nadir kovellit oluşumu göze çarpmaktadır (Şekil 8b). Pirit-I içinde gruplandırılmış olan konsantrik yapılı ve/veya süngerimsi toplanımların büyük çoğunluğunda merkezde gang mineralleri (olasılıkla kuvars?) göze çarpmakta, bazılarında $\mathrm{da}$ ise subhedral-euhedral sfalerit (sfalerit-I) veya pirit bir çekirdek gözlenmektedir (Şekil 8c). Ancak sfalerit (sfalerit-II) pirit II'yi anhedral bir yapıda ornatır şekilde de bulunur (Şekil 8c ve 8d).

Cevherleşmede üst kotlara doğru çıkıldıkça pirit miktarı azalmakta ve yatağın hedef metal kaynağını oluşturan $\mathrm{Cu}$ ve $\mathrm{Zn}$ sülfidler bollaşmaktadır. Subhedral-öhedral pirit (piritII) burada da gözlenir. Kuvars(?) gang ile beraber barit tarafından ornatılmıştır (Şekil 8e). Hem pirit-II, hemde baritin yaygın şekilde anhedral sfalerit (sfalerit-II), tenantit (tenantitI) ve kalkopirit-I tarafından ornatıldığı görülmektedir (Şekil 8e). Bu seviyelerde bariti ve onu ornatan tenantit-I ve kalkopirit-l'i ornatan, kolloform ve yer yer iskeletik formdaki üçüncü bir anhedral pirit fazının (pirit-III) varlığı da dikkat çekmektedir (Şekil 8f).

Süksesyonda pirit-II'yi ornatan tenantit-I'in sfalerit-II tarafından ornatıldığı ve her ikisininde galen tarafından ornatıldığı görülmektedir. (Șekil 9a). Bunların hepsini ornatan galen ise kalkopirit-I tarafından ornatılmaktadır (Şekil 9a). Tenantit daha sonraki evrede rekürans ile yeniden ortaya çıkmakta (tenantit-II, Şekil 9b), son evre kolloform pirit (pirit-III) ve konsantrik toplanımları ile kalkopirit-I'den ayrılan kalkopirit-II ile beraber ardalanmalı şekilde gelișmiș olarak gözlenmektedir (Șekil 9b). Bu fazların hepsi subhedral ve boşluk dolgusu şeklinde görülen kalkopirit-III ve sfalerit-III tarafından ornatılmaktadır (Şekil 9c). Stok sahasından alınan bir cevher örneğinde de piritII'nin sfalerit-II ve tenantit I tarafından ornatıldığı görülmektedir. Ayrıca tenantit içinde enarjt kapanımları da gözlenir (Şekil 9d). Lokasyonu tam olarak bilinmeyen bu stok sahası örneğinde diğer örneklerden farklı olarak bornit önemli miktardadır. Tenantit-I'in galen tarafından, galen'in ise bornit tarafında ornatıldığı göze çarpmaktadır. Bornitin aynı zamanda tenantit-I ve enarjitleri ornattığ 1 da görülmektedir. Son aşamada bornit, kalkozinkovellin ve kalkopirit-III tarafindan ornatılır. 

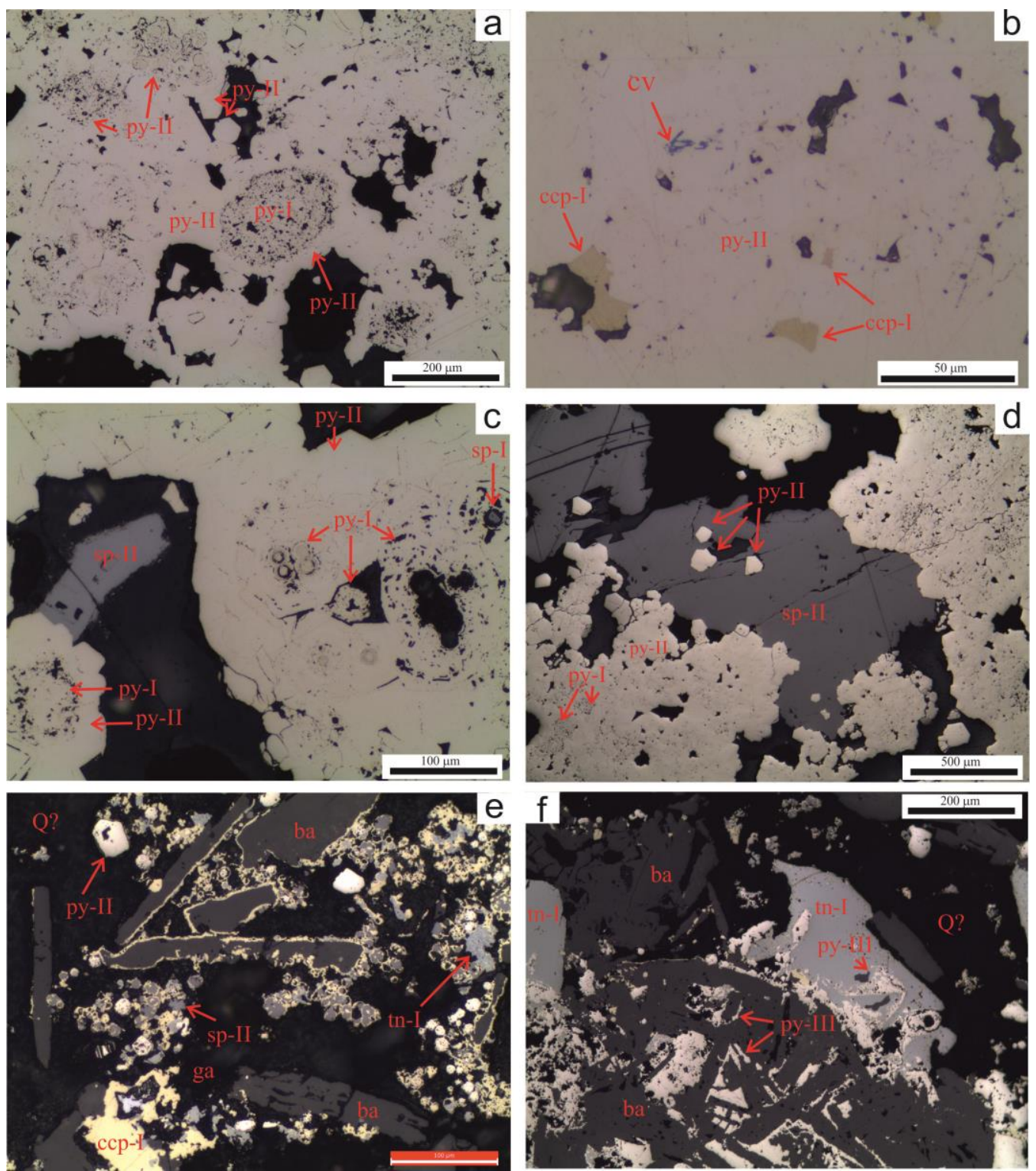

Şekil 8. (a) Lahanos yatağında gözlenen konsantrik ve bantll, yer yer süngerimsi ve/veya framboyid benzeri toplanımlar şeklinde piritlerin (py-I) öhedral-subhedral șekilli piritler (py-II) tarafından ornatımı, (b)öhedral-subhedral piritlerin kalkopirit (ccp-I) ve kovellin (cv) tarafından ornatılması, (c) çekirdeğinde subhedral sfalerit (sp-I) ve gang (kuvars?) bulunan konsantrik ve bantlı piritlerin (py-I) öhedral-subhedral pirit (py-II) ve anhedral sfalerit (sp-II) tarafından ornatımı, (d) Anhedral sfaleritin öhedral-subhedral piritleri (py-II) ve bunların çekirdeğindeki konsantrik ve bantlı piritleri (py-I) ornatımı, (e) Olasılıkla kuvars (Q?) ve öhedral-subhedral piritten (py-II) sonra gelişmiş baritin (ba) çeşitli cevher mineralleri tarafından ornatımı (ccp-I: kalkopirit-I, sp-II: sfalerit-II, ga: galen, tnI:tenantit-I), (f) Baritin (ba) kolloform ve yer yer iskeletik formdaki üçüncü bir pirit fazı (py-III) ve tenantit (tn-I) tarafindan ornatılması. 
Lahanos yatağı kesitlerinin incelenmesiyle bu karmaşık parajenetik ilișkilerden yola çıkılarak
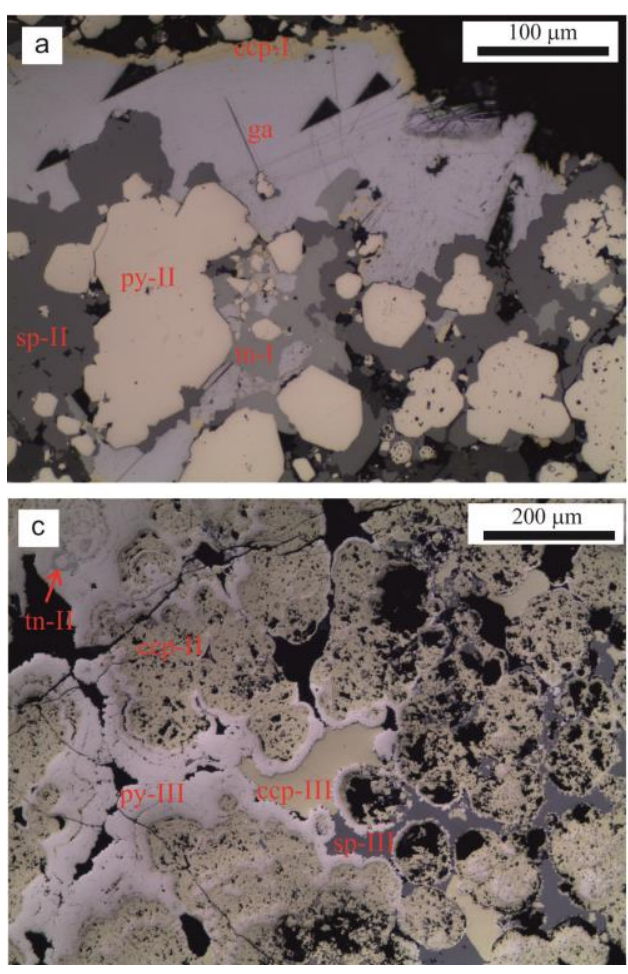

oluşturulan parajenetik tablo Şekil 10'da özetlenmiștir.
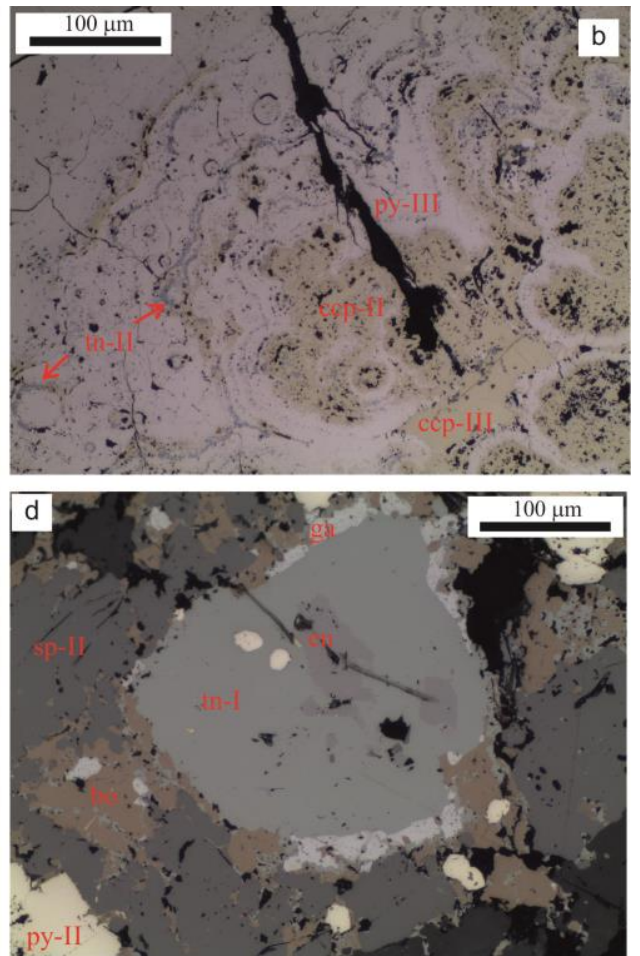

Şekil 9. (a) Süksesyonda öhedral-subhedral piriti (py-II) ornatan tenantit'in (tn-I) sfalerit (sp-II) tarafından ve her ikisininde galen (ga) tarafından ornatılması, galende kalkopirit I (ccp-I) tarafından ornatılmaktadır, (b) Tenantit rekürans ile yeniden ortaya çıkmakta (tn-II) ve kolloform pirit (py-III) ve kalkopirit-II (ccp-II) ile beraber ardalanmalı şekilde oluşmaktadır, (c) Subhedral ve boşluk dolgusu șeklinde son evre kalkopirit-III ve sfalerit-III, (d) Stok sahasından alınan cevher örneğinde pirit-II'nin sfalerit-II ve tenantit I tarafından ornatılması ve tenantit içinde enarjt kapanımları. Tenantit-I galen tarafından, galen'in ise bornit tarafinda ornatılmaktadır.

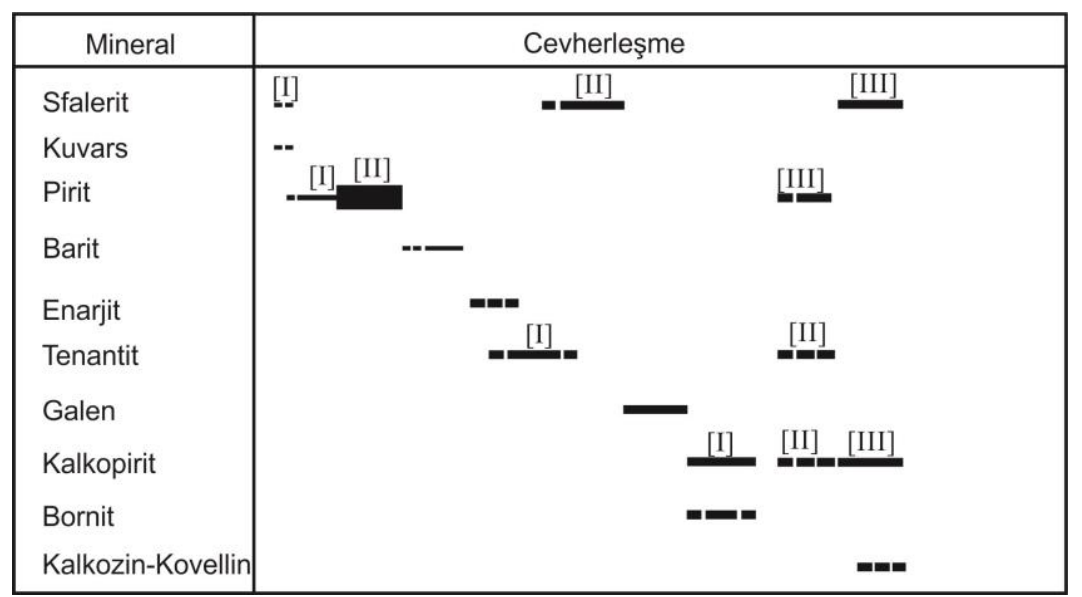

Şekil 10. Lahanos yatağından alınan örneklere ait genelleştirilmiș parajenez tablosu. 


\section{Tartışma ve Sonuçlar}

Bugüne kadar pek çok araştırmacı Doğu Pontid magmatik yayı volkanik ürünlerinde gelişmiş masif sülfür (VMS) cevherleşmelerinin Kuroko tip yatakların benzeri olduklarını ifade etmişlerdir [55, 86, 133, 136]. Revan ise yatakların Ural tip ve Kuroko tip arasında ortaç bir özellik sunduklarını ifade etmis ve ilk olarak Pejatoviç tarafından önerilen [47] "Pontid tip" ismi ile nitelendirmiştir [5]. Bu çalışma kapsamindan incelenen Lahanos ve Murgul masif sülfür cevherleşmeleri derin denizel açılma ortamında ve magmatik yay ile ilişkili açılma evrelerinde $[5,89]$ deniz tabanı hidtotermal aktivitesinin etkili olduğu süreçlerle ilişsili gelişmiş yataklardır. Her iki yatakta da ekonomik hedef metal $\mathrm{Cu}$ olmakla birlikte, parajenezlerinde yoğun pirit varlığı dikkat çeker. Bununla beraber yatakların özellikle mineralojik ve kimyasal açıdan önemli farklılıklar sunduğu görülmektedir. $\mathrm{Bu}$ bölümde bu çalıșmada gerçekleștirilen arazi ve laboratuvar gözlemleri ve önceki çalışmalar temelinde bu iki yatak arasındaki benzerlik ve farklılıklar ele alınarak bunun nedenleri yorumlanmaya çalışılacaktır.

Doğu Pontidlerin zıt uçlarında yer alan bu iki farklı cevherleşmenin öncelikle benzerliklerini ele alırsak, ilk aşamada mekan litolojilerden bahsetmemiz gerekir. Şekil 5'te verilen litostratigrafik korelasyon şemasına göre her iki yatakta da ana cevherleşmelerin benzer volkanik seviyeler (breşleşmiş ve altere dasitik kayaçlar) içinde bulunduğu ve örtü serilerinin benzer olduğu görülmektedir. Her iki yatakta da örtü cevherleşmelerin mekan/yan kayaların Kızılkaya Formasyonu'nun dasitik lav ve tüfleri oluşturmakta, her iki yatakta da konak kayacın breşleşmiş ve altere yapısına (silisleşme, serizitleşme, kaolinleşme, piritleşme) vurgu yapılmaktadır. Bir diğer benzerlik ise tavan litolojilerde görülür. Lahanos yatağının tavan litolojileri genel anlamda kırmızımsı grimsi ve dasitik-riyodasitik lav ve tüfler (veya hematitik dasit ve volkanoklastik seviyeler) olarak tanımlanırken [5, 97, 135, 136], Murgul yatağı örtü litolojileri mor renkli dasitik ve riyodasitik lav ve tüfler olarak tanımlanmaktadır. [97, 89]. Lokal olarak sırasıyla "genç dasit" ve "mor tüf/mor dasit" olarak ta isimlendirilen konak ve tavan serileri maden arama ve ișletme faaliyetlerinde önemli kılavuz seviye görevi görmektedir. İki yatak arasında örtü seriler arasında benzerlik bununla da sınırlı değildir.
Pollak tarafından "Lahanos Tepe dasiti" [97] ve Revan tarafından "biyotitli dasit" [5] olarak isimlendirilmiş olan ve Doğu Pontidlere ait genelleştirilmiş stratigrafide ise "Tirebolu Formasyonu" ile eşleştiği düşünülen hipabisal kayaçların (dasit bileşimli biyotit-kuvarsfeldspat porfiri [97, 135]) eşleniğininde Murgul yatağında Gökçe tarafından oldukça kalın şekilde örtü tüflerini üzerlediği ifade edilen "porfiri dasit" [89] olması mümkündür (Şekil 5). Bu temel benzerlikler, her iki yatağında yay volkanizmasının gelișimi sırasında iki farklı volkanik evre arasında gelişmiş cevherleşmeler olduğuna işaret eder.

Doğu Pontidlerde yer alan VMS yataklarının birçoğunun deniz tabanının hemen altında bulunan volkanik konak kayaçların ornatılmasıyla (deniz tabanı altı ornatımı) oluștuğu ve bir çoğunda cevherleșmenin masif tipten çok damar, saçınım ve ağsal tipte olduğu bilinmektedir [139]. Deniz tabanı altında gelişen düzensiz yapısal süreksizliklere infiltre olan hidrotermal akışkanlarla ilişkili bu tip cevherleșmeler deniz tabanında ve altında geliştikten sonra örtü kayaçların yerleşimi geliștiğinden bu kısımlarda konak kayaçlardaki gibi kuvvetli bir alterasyonun ve/veya cevherleşmenin varlığı beklenmez. Bununla beraber önceki çalışmalarda Murgul yatağının örtü (mor) tüflerinde özşekilli ve yaygın iri kristaller halinde piritlerin varlığının rapor edilmesi ilginçtir [89]. Söz edilen bu durumun ana cevher yerleşiminin zamanlaması ve belki rejüvenasyon gibi süreçlerin varlı̆̆ının daha detaylı irdelenmesini gerektirmektedir. $\mathrm{Bu}$ yönde bir çalıșma için ana cevherleșme ve ilișkili cevher fazların ve örtü kayada yer alan cevher minerallerinin direkt yaşlandırması gibi teknikler etkin araçlar olabilir.

Çalıșılan cevherleșmelerden bu çalıșma kapsamında incelenen örneklerin birbirlerinde farklılıklardan bahsedildiğinde ise en temel bașlık Doğu Pontid magmatik yayının en doğusunda yer alan Murgul yatağından incelenen örneklerinparajenez ve süksesyonun Lahanos'tan alınanlara göre daha basit olması olacaktır. Bunun temel nedeni çalışılan örneklerin her iki yatağın benzer zonlarından alınamamıș olmasıdır. Murgul yatağ ${ }_{1}$, sadece saçınım ve stokvörk cevherleşme içermektedir ve temelde cevher minerali olarak pirit ve kalkopirit, gang fazı olarak ise baskın kuvars ve buna eşlik eden serizitik ve arjilik alterasyon 
içerir. Murgul yatağından alınan örneklerde serizitleșme ve arjilikleșme ana sülfür cevherleșmesinin gözlendiği mekan kayacın silisleşmesi ve ağsal şekilde sülfidli ve silisli damarcıkların yerleșiminden önce gelişmiştir. Güncel deniz-tabanı hidrotermal sistemlerini (örn: Jade hidrotermal sahası, Okinawa hendeği yay-gerisi havzası, Japonya [140]) temel alan analojik bir yaklașımla, yatağın hali hazırda işletilen kesiminin Üst Kretase döneminde gelișmiş(mekan kaya yaşı) bir deniz-tabanı hidrotermal sisteminin hidrotermal akıșkan deşarjını takviye eden beslenme kanallarını temsil ettiği sonucuna varılabilir. $\mathrm{Bu}$ tip sistemlerde eğer deșarj olan hidrotermal akışkanın hidrostatik basıncı deniz suyununkine yakın veya büyükse beslenme kanalları üzerinde akışkan deşarjının gerçekleştiği deniz tabanı paleotopoğrafyasını yansıtacak sülfür tepeciklerinin bulunması beklenilir. Ancak işletmenin güncel durumunda paleoyüzey görülmemektedir. Bununla beraber, bu tip sülfür tepeciklerinin eşleniği olarak değerlendirilebilecek ince masif sülfür merceklerinin varlığından önceki çalışmalarda bahsedilmiștir [89]. Bu eksik sekans görüntüsünün, ana masif cevher zonlarının halihazırda işletilmiş olmasının yanında cevherleșmenin güncel konumuna yerleșimi sırasındaki tektonik faaliyet etkisi ile de olușmuș olabileceği değerlendirilebilir. Ancak önceki çalıșmalarda varlığı raporlanan masif sülfür merceklerinin de ince zonlar olarak not edilmesi ve saçınım ve ağsal cevherleșmenin yatak içinde baskın olması, cevherleşmenin oluşumu esnasında deniz suyu-hidrotermal akışkan arasındaki hidrostatik basınç farkının çok fazla olmadığını da önermektedir.

Lahanos yatağında ise cevherleșme, Murgul'un aksine, masif cevher açısından baskındır ve morfolojik olarak güncel deniz-tabanı hidrotermal sistemlerinde gelișen sülfür yığınlarının bir çeşit paleo-türevini andırmaktadır. Lahanos yatağında alt kotlarda cevherleşmenin başlangıç aşamasında gelişen piritlerin formu dikkat çekicidir. Parajenetik olarak en eski olan piritler (pirit-I) yaygın șekilde konsantrik ve bantll, yer yer süngerimsi ve/veya framboyit benzeri toplanımlar şeklindedir ve subhedral-öhedral piritler (piritII) tarafından ornatılmış/ çevrelenmiş halde gözlenirler. Bu tür dokular, deniz tabanı veya yakınında hidrotermal akıșkanın soğuk deniz suyu ile karıșımı ve hızlı soğumasına bağlı gelișebilmektedir, Bununla beraber aktif sistemlerde yürütülmüș detaylı çalıșmalar bu tür dokuların gelişmesi için bir tür altlığın varlığının da gerekli olduğu göstermektedir [141]. Bu tip yapılar için en olası altlıklar olarak biyotik tüp solucan toplulukları ve ipliksi bakteriler ya da akıșkanların erken dönemde düșük sıcaklıklı deşarjı ile oluşan silis-anhidrit-barit kovuklu yapıları önerilmektedir [141 ve orada verilen referanslar].

Lahanos yatağından alınan ve incelenen örneklerde düşük ısıda yaygın görülen dokular (konsantrik ve bantll, yer yer süngerimsi ve/veya framboyit benzeri) sunan pirit ile başlayan cevherleşmenin daha daha yüksek ısıda gelișebilecek (iri taneli ve öhedral-subhedral) dokudaki pirit ile çevrelenmesi, yukarıda anlatıldığı gibi bir tür altlık üzerine gelișen bir cevherleșmeye ișaret eder. Cevherleșmede üst kotlara doğru daha $\mathrm{Cu}-\mathrm{Zn}$ açısından zengin bir parajenezin varlığ Kuroko tipi yataklarda tipik olarak tanımlanan sarı cevherden siyah cevhere geçişi temsil ediyor gibi görünmektedir. Üst kotlara doğru parajenezde daha düșük ısıyı tanımlayan dokuların görülmesi ve süksesyonda sıklıkla gözlenen mineral tekrarlanması deniz tabanına deşarj olan sülfür açısından zengin hidrotermal çözeltinin zaman içinde evrimleştiğini, ancak buna ek olarak sürekli belirli aralıklarla da takviye edildiğini göstermektedir. Tekrarlanan hidrotermal çözelti takviyesi, gelişen karmaşık süksesyonu açılklayabilir bir senaryodur. Bununla beraber, bu çalışmada cevher minerallerinin kimyası hakkında detaylı bir irdeleme yürütülmediğinden bu olası süreçte akıșkan kimyasındaki değişimler hakkında bir yorum yapılması güçtür. Ancak cevherleşmede tekrarlanan fazların dokusal farklarından hareketle kimyalarında da bir varyasyonun olma olasılığı yüksektir.

Sonuç olarak, bu çalışma kapsamında örneklenen ve cevher mineralojileri açısından ele alınan Murgul ve Lahanos yatakları, aynı metalojenik kuşak içinde önemli oranda benzerlikleri yanında farklılıkları açısından da dikkat çekmektedir ve tipik deniz-tabanı hidrotermal sistemlerinin farklı seviyelerini iyi şekilde temsil etmektedir. Bu yatakların ve bölgedeki benzer kökendeki diğer yatakların parajenezlerinin, cevher mineral kimyalarının ve direkt olarak cevher radyometrik yaşlarının detaylı șekilde çalıșılması, ana cevherleșmelerin 


\section{DEU FMD 22(64), 117-136, 2020}

zamanlaması ve/veya cevherlesme sonrası rejüvenasyon süreçlerinin anlaşılmasında önemlidir. Bu tür bir araștırma perspektifi, bölgesel metalojenezik yap-bozun eksik parçalarının tamamlanmasında önemli ve kullanışlı birer araç olacaktır.

\section{Teşekkür}

Arazi ve örnekleme çalıșmalarına katkısı ve makalenin ilk seklini almasındaki sağladığı görüșlerinden dolayı Dr. Tolga OYMAN'a teşekkür ederim. Çalışma sırasında örneklemelerde yardımcı olan EtiBakır A.Ş. yöneticileri ve teknik personeline ayrıca tessekkür ederim. Makalenin son halini almasında sağladıkları yapıcı eleștiri ve katkılarından dolayı değerli hakemlere de teșekkürü borç bilirim. Bu çalısma Dokuz Eylül Üniversitesi özkaynaklar ile 2017.KB.FEN.010 no'lu Bilimsel Araștırma Projesi ile desteklenmiștir.

\section{Kaynakça}

[1] Galley, A.G., Hannington, M.D., Jonasson, I.R., 2007 Volcanogenic massive sulphide deposits, Mineral Deposits of Canada: A Synthesis of Major DepositTypes, District Metallogeny, the Evolution of Geological Provinces, and Exploration Methods, ed. Goodfellow, W.D., Geological Association of Canada Mineral Deposits Division, Special Publication No. 5 s. $141-161$.

[2] Akbulut, M., Oyman, T., Ciç̧ek, M., Selby, D., Özgenc, İ., Tokçaer, M., 2016. Petrography, mineral chemistry, fluid inclusion microthermometry and Re-Os geochronology of the Küre volcanogenic massive sulfide deposit (Central Pontides, Northern Turkey), Ore Geology Reviews, Cilt. 76, s. 1-18.

[3] Misra, K.C. 2000. Understanding Mineral Deposits Kluwer Academic Publishers, Dordrecht, Netherlands, $844 \mathrm{~s}$.

[4] Hamilton, W.J., 1842, Researches in Asia Minor, Pontus and Armenia. vol. I, II, London, 572s.

[5] Revan, M. K. 2010. Doğu Karadeniz Bölges Volkanojenik Masif Sülfid Yataklarının Tip Özelliklerinin Belirlenmesi. Hacettepe Üniversitesi, Fen Bilimleri Ensitüsü, Doktora Tezi, 320s, Ankara.

[6] Chaput, E., 1936, Türkiye'de jeolojik ve jeomorfolojik tetkik seyahatler: I.Ü. Coğr.Enst.Neș.,11, 326s.

[7] Arni, P., 1939, Tektonische Grundzüge Ostanatoliens und benachbarter Gebite: Veröff. Inst. Lagerstattenforsch. Türkei, Ser. B, 4, 90 s.

[8] Paréjas, E., 1940, La tectonique tranversale de la Turquie: Publ. Inst. Géol. Univ., İstanbul, N.S., 8, 244

[9] Lahn, E., 1940, Les structures géologiques de la région d'Erzurum: MTA Mecm., Cilt. 19, s. 233-243.

[10] Stchepinsky,V., 1945, Stratigraphie du bassin superiéur de la Kelkit çayı: M.T.A. Mecm., Cilt.33, s. 133-152.

[11] Kovenko, V. (1942): Artvin bölgesi Kuvarshan bakır madenleri. M.T.A. Mecm., Cilt.27, s.230-266.

[12] Wijkerslooth, P. de, 1946, Einiges über die Erzprovinz des östlichen SchwarzmeerKüstengebirges, insbesondere über die Kupferlagerstatte von Kuvarshane (Vil. CoruhTürkei): MTA Mecm., Cilt.35,102-120.
[13] Baykal, F., 1949, Of-Rize-Pazar kıyı dağları hakkında. M.T.A. Derleme Rapor No. 2198 (yayımlanmamış).

[14] Baykal, F., 1952, Kelkit-Şiran bölgesinde jeolojik arastırmalar. M.T.A. Derleme Rapor No. 2205 (yayımlanmamış)

[15] Erguvanlı, K., 1950, Trabzon-Gümüşhane arasındaki bölgenin jeolojik etüdü hakkında rapor. M.T.A. Derleme Rapor. No. 2273, 28s., Ankara.

[16] Yalçınlar, İ.,1952, İspir, Pazar, Arhavi ve Yusufeli arasındaki bölgenin jeolojisi. MTA Derleme Rapor No. 2022 (yayımlanmamış).

[17] Demirsü, A., 1955, Çıldır-Posof-Şavşat-Kemalpaşa bölgesinin jeolojik etüdü hakkında memuar. M.T.A. Rapor No: 2377 (yayımlanmamış).

[18] Gattinger, T.E., 1955, Kuzeydoğu Türkiye'de Çoruh ile Erzurum arasındaki bölgede yapılan jeolojik harita çalışmaları hakkında rapor. M.T.A. Derleme Rapor No. 2379 (yayımlanmamış).

[19] Gattinger, T.E., 1962, Explanatory text of the Geological Map of Turkey. Trabzon sheet. 1:500 000 scale. MTA Publ., Ankara.

[20] Nebert, K., 1961, Kelkit Cayı ve Kızılırmak (Kuzey Anadolu) nehirleri mecra bölgelerinin jeolojik yapısı. MTA Dergisi, Cilt.57, s.1-49.

[21] Ağralı, B., Akyol, E. and Konyalı, Y., 1965, Preuves palynologiques de l'existence du Dogger dans la région de Bayburt. Bulletin of the Mineral Research and Exploration Institute of Turkey, Cilt.65, s.45-57.

[22] Faure, D., 1967, Çoruh Nehri ile Karasu Çayı arasındaki stratigrafik seri ve Bayburt-Aşkale tektoniği hakkında rapor. M.T.A. Rapor No. 4099 (yayımlanmamış)

[23] Baydar, O., Erdoğan, B., Akyürek, B., Topçam, A., Kengil, R., Korkmazer, B., Kaynar, A. ve Selim, M., 1969, Yusufeli-Öğdem-Madenköy-Tortum Gölü ve Ersis arasındaki bölgenin jeolojisi. M.T.A. Derleme Rapor No. 5202 (yayımlanmamıs).

[24] Yılmaz, Y., 1972, Petrology and structure of the Gümüşhane granite and surrounding rocks: Londra Üniversitesi, Doktora Tezi, 260s, İngiltere.

[25] Yılmaz, Y., 1984, Türkiye'nin jeolojik tarihinde magmatik etkinlik ve tektonik evrimde ilişkisi T.J.K. Ketin Simpozyumu Bildirileri, 63-81.

[26] Stajanow, R., 1973, Pontidlerde Harşit nehri arasında volkanik taşların petrolojisi: Cumhuriyetin 50. yılı Yerbilimleri Kongresi Tebliğler Kitabı, 490-517.

[27] Seymen, İ., 1975, Kelkit vadisi kesiminde Kuzey Anadolu Fay zonunun tektonik özelliği. İTÜ Doktora Tezi, 192 s, İstanbul.

[28] Bergougnan, H., 1976, Structure de la chaine pontique dans le Haut-Kelkit (Nord Est de l'Anatolie). Bull. Soc. Geol. France, Cilt.7-18, s.675-686.

[29] Bergougnan, H., 1987, Etudes geologiques dans l'Estanatolien. These de doctorat, a l' Univ. Pierre et Marie Curie, Paris, 606-5.

[30] Çoğulu, E., 1975, Gümüşhane ve Rize granitik plütonlarının mukayeseli petrografik ve jeokronometrik etüdü (Petrological and geochronological studies in the Gümüşhane and Rize regions). Teknik Üniversite Matbaası, Doçenlik Tezi, $112 \mathrm{~s}$, İstanbul.

[31] Taner, M.F., 1977, Etude géologique et pétrographique de la région de Güneycellkizdere, située au sud de Rize (Pontides Orientales, Turquie). 
Ph.D. Thesis, Universite de Geneve, 180 s., Switzerland.

[32] Tokel, S., 1972, Stratigraphical and volcanic history of the Gümüşhane region, N.E. Turkey. University of London, Ph. D. Thesis, U.K.

[33] Tokel, S., 1973, Pontidlerin Mezozoyik ve Tersiyerdeki gelişimleri, bu gelișmelerin Kuzey Anadolu sismik zonu ile muhtemel ilgileri: Cumhuriyetin 50. Yılı Yerbilimleri Kong. Tebliğleri, 1-4, MTA yayını.

[34] Tokel, S., 1977, Doğu Karadeniz bölgesinde Eosen yaşlı kalk-alkalen andezitler ve jeotektonizma; Türkiye Jeoloji Kurultayı Bült., Cilt. 20, s.49-54.

[35] Tokel, S., 1985, Pontidlerdeki uyumsuz elemen değişimlerinin transversal dağılımı ve dalım yönü tayini: Türkiye Jeoloji Kurultayı, Bildiri Özleri, s. 23.

[36] Peccerillo, A. and Taylor, S.R., 1975, Geochemistry of Upper Cretaceous volcanic rocks from the Pontic Chain, Northern Turkey. Bull. Volcan., Cilt. 39/4 s.557-569.

[37] Peccerillo, A. and Taylor, S.R., 1976, Geochemistry of Eocene calcalkaline volcanic rocks from Kastamonu area, Northern Turkey. Contr. Mineral. Petrol., Cilt 58, s. 63-81.

[38] Ağar, Ü., 1977, Demirözü (Bayburt) ve Köse (Kelkit) bölgesinin jeolojisi. Doktora Tezi, KTÜ yayını, $59 \mathrm{~s}$. Trabzon,

[39] Pelin, S., 1977, Alucra (Giresun) güneydoğusu yöresinin petrol olanakları bakımından jeolojik incelemesi. K.T.Ü. yayını, No:87, 105 s., Trabzon.

[40] Altun, Y., 1971, Murgul-Karatepe mevkii doğusunun jeolojik etüd raporu. M.T.A. Derleme Rapor No. 4807, 9s., Ankara.

[41] Altun, Y., 1976, Artvin-Murgul yataklarının jeolojik etüd raporu. M.T.A. Derleme Rapor No. 6317, Ankara.

[42] Altun, Y,, 1977, Çayeli- Madenköy bakır- çinko (Cu$\mathrm{Zn)}$ yatağının jeolojisi ve cevherleșmeyle ilișkin sorular: MTA derg, Cilt.9, s.9-21

[43] Çağatay, M.N., 1977, Development of the geochemical exploration techniques for massive sulphide ore deposits, Eastern Black Sea Region, Turkey. Ph. D. Thesis. Univ. London.

[44] Cağatay, N., 1980, Doğu Karadeniz Bölgesi volkanojenik masif sülfid yatakların hidrotermal alterasyonu. Türkiye Jeo. Kur. Bült. Cilt.23, s.69-78.

[45] Cağatay, M.N. 1993, Hydrothermal alteration associated with volcanogenic massive sulfide deposits: examples from Turkey. Economic Geology, Cilt.85, s.606-621.

[46] Çağatay,M.N., Eastoe, J.E., 1995. A sulfur isotope study of volcanogenicmassive sulfide deposits of the eastern Black Sea province, Turkey. Mineral Deposita Cilt.30, s.55-66.

[47] Pejatoviç, S., 1979, Metallogeny of the Pontide-type massive sulfide deposits; MTA Publ. No. 177.

[48] Gedikoğlu, A., 1978, Harşit granit karmaşığı ve çevre kayaçları (Doğankent-Giresun). K.T.Ü. Yer Bilimleri Fakültesi, Doçentlik Tezi, 176 s., Trabzon.

[49] Gedikoğlu, A., Pelin, S. and Özsayar, T., 1979, The main lines of geotectonic development of the Eastern Pontids in the Mesozoic area. Geocome-1, first geological Congress of the Middle East: M.T.A. Publ., 555-580.
[50] Sengör, A.M.C., 1979, The North Anatolian transform fault, its age, offset and tectonic significance: Journal of the Geological Society of London, 136, 269-282.

[51] Sengör, A.M.C., Yılmaz, Y. 1981. Tethyan evolution of Turkey: a plate tectonic approach. Tectonophysics Cilt.75, s. 181-241.

[52] Akıncl, Ö.T., 1980, The major copper metallogenetic units and genetic igneous complexes in Turkey. In: Jankovic, S. and Sillitoe, R.H. (eds.) European Copper Deposits. 199-208.

[53] Akıncl, Ö.T., 1981, Eastern Pontide volcanosedimantery belt and associated massive sulfide deposits. Econ. Geo. Mon. 1, 196-214.

[54] Akıncl, Ö.T., 1984, The Geology and the metallogeny of the Eastern Pontides (Turkey). 1984 Dünya Jeoloji Kongresi Bildiri Özetleri Kitabı, 197-198.

[55] Akıncl, Ö.T., 1985, The Eastern Pontide volcanosedimentary belt and associated massive sulphide deposits, In: Dixon, J.E. and Robertson, A.H.F. eds., The Geological Evolution of the Eastern Mediterranean. Geological Society Special Publication, No. 17, 415-428.

[56] Özsayar, T., Pelin, S. ve Gedikoğlu, A., 1981, Doğu Pontidler'de Kretase (Cretaceous in the Eastern Pontides). Karadeniz Teknik Üniversitesi Yerbilimleri Dergisi Jeoloji, 1, 65-114.

[57] Kahraman, İ., 1981, Giresun-Görele-Tirebolu yöresinin jeolojisi ve maden yatakları. MTA Derleme Rapor No.1785, Ankara.

[58] Kahraman, İ., 1984, Giresun-Tirebolu-Espiye yöresinin $\mathrm{Cu}-\mathrm{Pb}-\mathrm{Zn}$ ve $\mathrm{Mn}$ cevherlesmeleri maden jeolojisi raporu. MTA Derleme Rapor. No. 8028, Ankara.

[59] Ercan, T. and Gedik, A., 1983, Pontidlerin volkanizması, Jeo. Müh. Derg.,18, 3-22.

[60] Bektaş, 0., 1983. Kuzeydoğu Anadolu magmatik yayındaki (I) tipi granitler ve jeotektonik konumları: 37. Türkiye Jeoloji Bilimsel ve Teknik Kurultayı Bildiri özetleri kitabı, 49-50.

[61] Bektaș, O., 1984, Doğu Pontidlerde Üst Kretase yașlı şoşonitik volkanizma ve jeotektonik önemi. KTÜ Dergisi, 3, 53-62.

[62] Bektaș, O., Pelin, S. ve Korkmaz, S., 1984, Doğu Pontid yay gerisi havzasında manto yükselimi ve polijenetik ofiyolit olgusu: Türkiye Jeo. Kur. Ketin Simpozyumu, 175-189.

[63] Bektaş, O. ve Gedik, İ., 1987, Düşük TiO2'li lositli alkalen volkanizmanın Doğu Pontid Arkı (Kuzeydoğu Türkiye) ve ark gerisi ofiyolitleri ile olan ilișkileri. TJK Bildiri Özleri, Ankara, s. 19.

[64] Bektaş, O., Van, A. ve Boynukalın, S., 1987, Doğu Pontidler'de (Kuzeydoğu Türkiye) Jura volkanizması ve Jeotektoniği. Türkiye Jeo. Bül., Cilt. 30, s.9-18.

[65] Bektaş, O. and Yılmaz, C., 1995, Mesozoic evolution of the Eastern Pontides (NE Turkey) opening of the Neotethys (from rifting to drifting) as a back arc basin. International Ophiolite Symposium, Pavia, Program and Abstract, 19-20.

[66] Bektaş, O., Şen, C., Atıcı, Y., and Köprübaşı, N., 1999, Migration of the Upper Cretaceous subductionrelated volcanism towards the back-arc basin of the eastern Pontide magmatic arc (NE Turkey). Geol Jour. Cilt.34, s.95-106. 


\section{DEU FMD 22(64), 117-136, 2020}

[67] Akdeniz, N., 1988, The regional tectonic framework of the Permo-Carboniferous of the Demirözü area. Türkiye Jeoloji Bülteni, Cilt.31, s.71-80.

[68] Akdeniz, N., Akçaren, F. ve Timur, E., 1994, Asskaleİspir arasının jeolojisi. M.T.A. Derleme Rapor No. 9731 (yayımlanmamış).

[69] Yılmaz, C., 1993, Accumulation rates of JurassicLower Cretaceous sediments in the southern zone of the eastern Pontides. Giornale di Geologia, Cilt.55/2, s.131-145.

[70] Yılmaz, Y., Tüysüz, O., Yiğitbaş, E., Genç, Ş.C. and Şengör, A.M.C., 1997, Geology and tectonic evolution of the Pontides. In: A.G. Robinson, ed., Regional and Petroluem Geology of the Black Sea and Surrounding Region. AAPG Memoir 68, 183-226.

[71] Yılmaz, A., Adamia, S., Lordkipanidze, M., Yılmaz, T. Kurt, İ., Abesadze, G., Lazarashvili, T., Beradze, R., Salukvadze, N., Kuloshvili, S., and Özkan, M., 2001, A Study of tectonic units of the area along TurkishGeorgian border. Yılmaz, A., Engin, T. ed. Geologica studies of the area along Tukish-Georgian Border General Directorate of Mineral Research and Exploration, Ankara, 388p.

[72] Yılmaz, C., Şen, C. and Özgür, S., 2003 Sedimentological, palaeontological and volcanic records of the earliest volcanic activity in the Eastern Pontide Cretaceous volcanic arc (NE Turkey). Geol Carp., Cilt.54, s.377-384.

[73] Keskin, İ., Korkmaz, S., Gedik, İ., Ateş, M., Gök, L., Küçümen, Ö. ve Erkal, T., 1990, Bayburt dolayının jeolojisi. MTA Derleme Rapor No.8995 (yayımlanmamış).

[74] Keskin, İ., Yergök, A.F., Kara, H., Dönmez, M. ve Aslan, M., 1998, Ünye-Fatsa-Kumru-Korgan (Ordu İli) dolayının jeolojisi. M.T.A. Derleme Rapor No. 10182 Ankara.

[75] Okay, A.I.., 1989, Tectonic units and sutures in the Pontides, northern Turkey, In: Şengör, A.M.C. ed. Tectonic evolution of the Tethyan region: NATO ASI Series C259, Kluwer, Dordrecht, p. 109-116.

[76] Okay, A.I., 1993, Geology and tectonic evolution of the Pulur (Bayburt) region (in Turkish): Report of the Turkish Petroleum Exploration Division, Ankara, No. 3415, $86 \mathrm{~s}$.

[77] Konak, N., Ercan, T. ve Bilgin, Z.R., 1991, Artvin-Oltu arasındaki Jura öncesi kayaların tanımı ve yapısal özellikleri: Ankara Üniv. Suat Erk Jeoloji Simpozyumu Bildiri Özleri.

[78] Konak, N. and Hakyemez, Y., 2001, Tectonic units of the easternmost part of the Pontides: stratigraphical and structural implications. Proceedings 2nd Int Symp. Petrol. Geol. Hydrocarbon Potential Black Sea Area, 22-24.9.1996, Şile, Istanbul. Turk. Assoc. Petrol. Geol. Sp. Publ. 4, s.93-103.

[79] Konak, N., Hakyemez, Y., Bilgic, T., Bilgin, Z.R Hepșen, N. ve Ercan, T., 2001, Kuzeydoğu Pontidlerin jeolojisi, M.T.A. Derleme Rapor No. 10489, Ankara.

[80] Güner, S., Güç, A.R., Eroğlu, C.İ., Musaoğlu, A., Boğușlu, M., Tosun, C.Y., Kırcl, M. ve Yaprak, S., 1986, GiresunKelkit-Siran ve Alucra yöresi $\mathrm{Cu}-\mathrm{Pb}-\mathrm{Zn}, \mathrm{Fe}$ ve Barit cevherleșmelerine ait maden jeolojisi raporu. MTA Derleme Rapor No. 8040, Ankara.

[81] Güner, S., Dursun, A.,Doksanbir, T., Yılmaz, Z.,Bayraktar, S. ve Deniz, N., 1999, Gümüșhane-
Bayburt-İspir-Yusufeli yörelerine ait epitermal altın aramaları. MTA Derleme Rapor No. 10257, Ankara.

[82] Güner, S, Yazıcı, E., Dursun, A., Yılmaz, H., Ağan, A. ve Yılmaz, Z., 2003, Gümüșhane yöresi Epitermal altın aramaları prospeksiyon raporu. MTA Derleme Rapor No. 10743 , Ankara.

[83] Güven, İ.H., 1998, 1/100 000 ölçekli Türkiye Jeoloji Haritaları, Tortum-D31 paftası, MTA, Ankara.

[84] Gedik, A., Ercan, T., Korkmaz, S. and Karataş, S., 1992, Petrology of the magmatic rocks in the area between Rize. Fındıklı and Çamlıhemşin (eastern Blacksea region) and their distribution in the Eastern Pontides (in Turkish): Türkiye Jeoloji Bülteni, Cilt.35, s.15-38.

[85] Buser, S. (1970): Murgul bakır ocağı çevresinin jeolojisi. M.T.A. Rap., no. 5073 (yayınlanmamış), Ankara.

[86] Craig H. B. Leitch, 1981; Mineralogy and Textures of the Lahanos and Kızılkaya Massive Sulphide Deposits, Northeastern Turkey, and their Similarity to Kuroko Ores. Mineral. Deposita, Cilt.16, s.241 257

[87] Gedikoğlu, vd., 1982. Gölköy (Ordu) yöresinde bir paleokaldera ile cevherleşmelerin konumu arasındaki ilişkiler: K.T.Ü. Yerbilimleri Dergisi, Cilt.2/1-2, s.117-130.

[88] Geoffroy, J. (1960): Çayeli, Pazar ve Ardeșen bölgelerinin jeolojisi ve maden yatakları (vilâyet Rize).M.T.A.Rap, no. 3073 (yayınlanmamıs), Ankara.

[89] Gökçe, 2001. Çakmakkaya ve Damarköy (Murgul Artvin) Bakır Yataklarında Sıvı Kapanımı, Oksijen ve Hidrojen İzotopları Jeokimyası İncelemeleri ve Yatakaların Oluşumu Açısından Düşündükleri, Türkiye Jeoloji Bülteni Cilt 44, s.23-37.

[90] Gökçe, A., Spiro, B., 2000. Sulfur-isotope characteristics of the volcanogenic $\mathrm{Cu}-\mathrm{Zn}-\mathrm{Pb}$ deposits of the eastern Pontide region, Northeastern Turkey. Int. Geol. Rev. Cilt. 42, s.565-576.

[91] Karamata, S., vd, 1979. Lead and copper contents of igneous rocks from the Pontides and the Anatolides and their significance, Geocome I, s.347-366.

[92] Koprivica, D., 1979. Geological correlation in the Hopa-Artvin-Şavşat ares: Geocome I, s.379-410.

[93] Kraeff, A. (1963): Hopa-Murgul bölgesi jeolojisi ve maden yatakları. M.T.A. Derg., Cilt.60, s.44-59.

[94] Mado, H., 1972, Geology and mineralization of the copper ore deposits in the Murgul mine, northeastern Turkey: MTA Rap., 1103, (yayımlanmamış), Ankara.

[95] Özgür, N. ve Palacios, C.M., (1990). Doğu karadeniz metalojenik kuşağında bulunan volkanojenik kökenli Murgul bakır yatağının jeokimyasal önemli indikatör elementleri: MTA Dergisi, Cilt.111, s.119-132.

[96] Peccerillo, A., ve Taylor, 1975. Geochemistry of Upper Cretaceus volcanic rock from the Pontic chain, Northern Turkey: Bull Volcanologique, Cilt.39, s.113.

[97] Pollak, A. (1961) : Karadeniz sahilinde, Giresun vilâyeti dahilinde Lahanos cevher yataklan. M.T.A. Derg., Cilt. 56, s. 40-52.

[98] Revan, vd., 2010. Doğu Karadeniz Bölgesi Masif Sülfit Yataklarındaki (Lahanos, Killik ve Cayeli) Fosil İzlerine Ait İlk Bulgular, MTA Dergisi, Cilt.140, s.7581.

[99] Revan, K., 2015. Volkanojenik Masif Sülfit (VMS) Bölgelerinin Küresel Ölçekte Karşılaştırılması (IGCP- 


\section{DEU FMD 22(64), 117-136, 2020}

502). Doğal Kaynak ve Ekonomi Bülteni (2015) Cilt 20, s.97-113.

[100]Sawa, T. ve Sawamura, K., 1970, Murgul cevher yatağı ve çevresi hakkındaki rapor: Etibank Rap. 24/300, 24 s. (yayımlanmamıș). Ankara.

[101]Schneider, H.-J.; Özgür, N. ve Palacios, C.M., 1988 Relationship between alteration, rare eart element distribution, and mineralization of the Murgu copper deposit, northeastem Turkey: Econ. Geol., Cilt.83, s.1238-1246.

[102]Tuğal, H.T., 1969. Pyritic sulphide deposits of the Lahanos mine ares, Eastern Black sea Region, Turkey: Doktora tezi, Durham Üniversitesi (İngiltere) yayınlanmamış.

[103]Vujanovic, V, 1974, Doğu Karadeniz bölgesi, Yayı kesiminde bulunan sülfit maden yataklarının mineraloji, parajenez ve köken özellikleri: MTA Derg, Cilt.82, s.21-35

[104]Zimmer, E. (19730): Arhavi ve Peronit mintıkas bakır yatakları hakkında rapor. M.T.A. Rap., no. 344 (yayınlanmamış), Ankara. (1937/>): Murgul bakır yatağı hakkında nihâî raporlar. M.T.A. Rap., no. 349 (yayınlanmamış), Ankara.

[105]Willgallis, A.; Özgür, N. ve Siegmann, H., 1990 Microprobe sludy of Se-and Te-containing complex sulphide ore of the copper deposit Murgul, Mi Turkey: Kur. 3. Mineral. Cilt. 2, s.145-148.

[106]Revan, M.K., Genç, Y., Maslennikov, V.V., Ünlü, T. Delibaş, O., Hamzaçebi, S. 2013. Doğu Karadeniz bölgesi (KD Türkiye) volkanojenik massif sülfid yatakları cevher fasiyeslerine ait bazı özgün bulgular, Maden tetkik ve Arama Dergisi, Cilt.147 s.73-90.

[107]Richards, J.P. 2015. Tectonic, magmatic, and metallogenic evolution of the Tethyan orogen: From subduction to collision. Ore Geology Reviews Cilt. 70 s. 323-345.

[108]Kuşçu, İ. 2013. Metallogeny of Turkey A diverse collisional and post-collisional environment for mineral deposits. Mining Turkey Cilt.3, Sayı 5, s. 3239.

[109]Jankovic, S., Petrascheck, W. 1987. Tectonics and metallogeny of the Alpine - Himalayan belt in the Mediterranean area and western Asia: Episodes Cilt.10, s. 169 - 175

[110] Kuşçu, İ., 2019. Skarns and Skarn Deposits of Turkey. ss 283-336. Pirajno, F., Ünlü, T., Dönmez, C., Şahin, M.B., ed. 2019. Mineral Resources of Turkey, Springer Nature Switzerland AG, Switzerland, 749s.

[111] Kuşçu, İ., Tosdal, R.M., Gençalioğlu-Kuşçu, G., 2019. Porphyry-Cu Deposits of Turkey.ss 337-425. Pirajno, F., Ünlü, T., Dönmez, C., Sahin, M.B., ed. 2019. Mineral Resources of Turkey, Springer Nature Switzerland AG, Switzerland, 749s.

[112]Adamia, S.A., Lordkipanidze, M.B., Zakariadze, G.S., 1977. Evolution of an active continental margin as exemplified by the Alpine history of the Caucasus. Tectonophysics, Cilt 40, s.183-189.

[113]Adamia, S.A., Chkhotua, T., Kekelia, M. Lordkipanidze, M.B., Shavishvili, I., Zakariadze, G. 1981. Tectonics of the Caucasus and adjoining regions-implications for the evolution of the Tethys Ocean. J. Struct. Geol., Cilt.3 (4), s.437-447.

[114]Dilek, Y., Imamverdiyev, N., Altunkaynak, S., 2010. Geochemistry and tectonics of Cenozoic volcanism in the Lesser Caucasus (Azerbaijan) and the periArabian region: collision-induced mantle dynamics and its magmatic fingerprint. Int. Geol. Rev., Cilt.52 (4-6), s.536-578.

[115]Rice, S.P., Roberson, A.H.F., Ustaömer, T., İnan, T., Taslı, K., 2009. Late Cretaceous-Early Eocene tectonic development of the Tethyan Suture Zone in the Erzincan area, eastern Pontides, Turkey. Geol. Mag., Cilt. 146 (4), s.567-590

[116]Ustaömer, T., Robertson, A.H.F., 1996. Paleotethyan tectonic evolution of the North Tethyan margin in the central Pontides, N Turkey. Erler, A., Ercan, T., Bingöl, E., Örçen, S., ed., International Symposium on the Geology of the Black Sea Region, Proceedings-I, s. 2433.

[117]Dewey, J.F., Pitman, W.C., Ryan, W.B.F., Bonnin, J., 1973. Plate tectonics and evolution of the Alpine system. Geol. Soc. Am. Bull., Cilt.84, s.3137-3180.

[118]Eyuboglu, Y., Dilek, Y., Bozkurt, E., Bektas, O., Rojay, B., Şen, C., 2010. Geochemistry and geochronology of a reversely-zoned, Alaskan-type ultramafic-mafic complex in the Eastern Pontides, NE Turkey. Santosh, M., Maruyama, S. ed., A tribute to Akiho Miyashiro. Gondwana Res., Cilt. 18, s. 230-252.

[119]Eyuboglu, Y, Bektaş, O., Pul, D., 2007. Mid-Cretaceous olistostromal ophiolitic melange developped in the back-arc basin of the eastern Pontide magmatic arc (NE Turkey). Int. Geol. Rev., Cilt. 49 (12), s.11031126.

[120]Eyuboglu, Y., Santosh, M., Yi, K., Bektaș, O., Kwon, S., 2012. Discovery of Miocene adakitic dacite from the Eastern Pontides Belt and revised geodynamic model for the late Cenozoic Evolution of eastern Mediterranean region. Lithos, Cilt.146-147, s.218232.

[121]Eyüboğlu, Y., Santosh, M., Keewook, Y., Tüysüz, N., Korkmaz, S., Akaryali, E., Duda, F.O., Bektas, O. 2014. The Eastern Black Sea-type volcanogenic massive sulfide deposits: Geochemistry, zircon $\mathrm{U}-\mathrm{Pb}$ geochronology and an overview of the geodynamics of ore genesis. Ore Geology Reviews, Cilt.59, s. 29-54.

[122]Yilmaz, Y., Tüysüz O., Yiğitbaș, E., Genç, Ș.C., Şengör, A.M.C., 1997. Geology and tectonic evolution of the Pontides. ss 183-226. Robinson, A.G., ed. 1997. Regional and Petroleum Geology of the Black Sea and Surrounding Region. AAPG Special VolumesVolume AAPG Memoir 68.

[123]Bektaş, O., Yılmaz, C., Taslı, K., Akdağ, K., Özgür, S., 1995. Cretaceous rifting of the eastern Pontide carbonate platform (NE Turkey): the formation of carbonates breccias and turbidites as evidences of a drowned platform. Geologia, Cilt.57 (1-2), 233-244.

[124]Eyuboglu, Y., Bektaş, O., Seren, A., Maden, N., Jacoby, W.R., Özer, R., 2006. Three axial extensional deformation and formation of the Liassic rift basins in the Eastern Pontides (NE Turkey). Geol. Carpath., Cilt. 57 (5), s.337-346.

[125]Akbulut, M., González-Jiménez, J.M., Griffin, W.,L., Belousova, E., O’Reilly, S.Y., McGowan, N., Pearson, N.J. 2016. Tracing ancient events in the lithospheric mantle: A case study from ophiolitic chromitites of SW Turkey. Journal of Asian Earth Sciences, Cilt. 119, 1-19.

[126]Okay, A.I., Tüysüz, O., 1999. Tethyan sutures of northern Turkey. ss 475-515. Durand, B., Jolivet, L., 
DEU FMD 22(64), 117-136, 2020

Horváth, F., Séranne, M. ed. 1999. The Mediterranean Basins: Tertiary Extension within the Alpine Orogen. Geological Society, London, Special Publications, 156.

[127]Maucher, A., Schultze-Westrum, H. ve Zankl, H., 1962, Geologischlagerst ättenkundliche Untersuchungen im Ostpontischen Gebirge: Bayerische Akad. Wiss. Mathematik-Naturw., Cilt. 109, 97s.

[128]Akın, H., 1979, Geologie, Magmatismus und Lagerstättenbildung im Ostpontischen Gebirge/Türkei aus der Sicht der Plettentektonik: Geol. Rundschau, Cilt.68, s.253-283.

[129]Zerener, M. 2005. Doğu Karadeniz Bölgesi Metalojenik Kuşağında bulunan Murgul Masif Sülfid Yatağının Hidrotermal Çözeltileri ve Gelişimi. Süleyman Demirel Üniversitesi, Fen Bilimleri Enstitüsü, Yüksek Lisans Tezi, 43 s, Isparta.

[130]Özgür, N. 1993. Volcanogenic massive sulfide deposits in the East Pontic Metallotect, NE Turkey, Resource Geology Special Issue, Cilt.17, s180-185.

[131]Engin, T., Er, M., Yüce, N., Buadze, V., Bakhadze, Y. 2002. Metallogenic Studies of the Northeastern Black Sea Region of Turkey (east of Trabzon) and Southwestern Georgia. Ss 228-241. Yllmaz, A., Adamia, S., Engin, T., Lazarashvili, T., ed. 2002. Geological Studies of the Area Along the TurkishGeorgian Border. General Directorate of Mineral Research and Exploration (MTA) and State Department of Geology-Georgia (SDG) \& Geological Institute of the Academia of Sciences-Georgia (GIN) Türkiye, 434s.

[132]Köprübaşı, N., Çiftçi, E., Cordan, S., Köprübaşı, N., Özkul, C., Şişman Tükel, F. 2014. Comparative geochemical study of soils developed on characteristic black and yellow polymetallic massive sulfide deposits in Eastern Pontides (NE Turkey) Turkish Journal of Earth Sciences, Cilt.23, 129-146.

[133]Çiftçi, E., Yalçınalp, B., Kolaylı H., Hagni, R.D. 2001. Textural, mineralogical and paragenetic charactersitics of Murgul Deposit (Artvin-NE Turkey) - An example to the Kuroko-type volcanogenic massive sulfide deposits. Geosound Yerbilimleri, Cilt.38, s. 11-25.

[134]Gümüş, A. 1964. Genesis of Some Cupreous Pyrite Deposits of Turkey. CENTO Symposium on Mining Geology and the Base Metals, September 14-28, Ankara, 147-154.

[135]Tugal, H. T. 1969. The pyretic sulphide deposits of the lahanos mine area, eastern black sea region, Turkey, Durham theses, Durham University. Available at Durham E-Theses Online: http://etheses.dur.ac.uk/9628/, 182 s., Durham, UK

[136]Çiftçi, E., Hagni, R. D. 2005. Mineralogy of the Lahanos Deposit a Kuroko-Type Volcanogenic Massive Sulfide Deposit from the Eastern Pontides (Giresun-NE Turkey), Türkiye Jeoloji Bülteni, Cilt. 48 (1), s. 55-64.

[137]Willgallis, A., Özgür, N., Siegmann, E. 1989. Microprobe study of Se-and Te-containing complex sulphide ore of the copper deposit Murgul, NETurkey. Eur. J. Mineral, Cilt. 2, s.145-148.

[138]Zaykov, V., Novoselov, K., Kotlyarov, V. 2006. Native gold and tellurides in the Murgul and Cayeli volcanogenic $\mathrm{Cu}$ deposits (Turkey). International Geoscience Programme Project 486 [IGCP-486]
Gold-Silver-Telluride-Selenide (Au-Ag-Te-Se) Deposits (2004-2008) Proceedings of the 2006 Field Workshop, 24-29 September, İzmir, 167-172.

[139] Revan, M.K., Genc, Y., Maslennikov, V.V., Ünlü, T., Delibaş, O., Hamzaçebi, S., 2013. Doğu Karadeniz bölgesi (KD Türkiye) volkanojenik massif sülfid yatakları cevher fasiyeslerine ait bazı özgün bulgular, Maden tetkik ve Arama Dergisi, Cilt.147, s. 73-90

[140]Halbach, P., Nakamura, K., Wahsner, M., Lange, J., Sakai, H., Käselitz, L., Hansen, R.-D., Yamano, M., Post, J., Prause, B., Seifert, R., Michaelis, W., Teichmann, F., Kinoshita, M., Märten, A., Ishibashi, J., Czerwinski, S., Blum, N., 1989. Probable modern analogue of Kuroko-type massive sulphide deposits in the Okinawa Trough back-arc basin. Nature, Cilt. 338, s. 496-499.

[141]Taylor, C.D., Sutley, S.J., Lichte, F.E. Mineralogical, Textural, and Metal Residence Studies of Primary,Recrystallized, and Remobilized Ores of the Greens Creek Deposit. Taylor, C.D. and Johnson, C.A. ed. 2010. Geology, Geochemistry, and Genesis of the Greens Creek Massive Sulfide Deposit, Admiralty Island, Southeastern Alaska, USGS Professional Paper 1763, 429s. 